\title{
Trends in the Synthesis and Functionalization of Guaianolides
}

\author{
Alejandro Santana, ${ }^{[a]}$ José M. G. Molinillo, ${ }^{[a]}$ and Francisco A. Macías*[a]
}

Keywords: Total synthesis / Natural products / Terpenoids / Lactones / Guaianolides

Guaianolides constitute a large and diverse group of biologically active sesquiterpenes. Guaianolide and seco-guaianolides can also be used as, for example, scaffolds for the development of new active molecules that are readily accessible by synthetic methods. Nevertheless, these lactones often have complex structures that make their synthesis difficult. The aim of this microreview is to provide an overview of the developments in guaianolide synthesis by the two major syn- thetic strategies: semi-synthesis and total synthesis. Partial and total syntheses of guaianolides are described, with particular emphasis placed on the methods reported in the last decade. The methods discussed include rearrangements, cycloadditions, ring-closing metathesis, the use of transitionmetal catalysts, photochemical reactions, and other recently developed techniques as key steps.

\section{Introduction}

Sesquiterpene lactones (SLs) are amongst the most abundant natural products. More than 8000 structures have been reported, and they have broad structural and functional di-

[a] Department of Organic Chemistry, Institute of Biomolecules (INBIO), School of Science, University of Cadiz,

C/ República Saharaui, 7, 11510 Puerto Real, Spain

E-mail: famacias@uca.es

http://fqm286.uca.es versity ${ }^{[1]}$ SLs have been isolated and identified from numerous species of higher and lower plants, chiefly from species of Compositae. These compounds are primarily classified on the basis of their carbocyclic skeletons into pseudoguaianolides, guaianolides (including seco-guaianolides), germanocranolides, eudesmanolides, heliangolides, and hyptocretenolides, with guaianolides being the most common.

Guaianolides are based on a 5,7,5-ring system that exists in two main forms: the guaian-6,12-olide and the guaian-

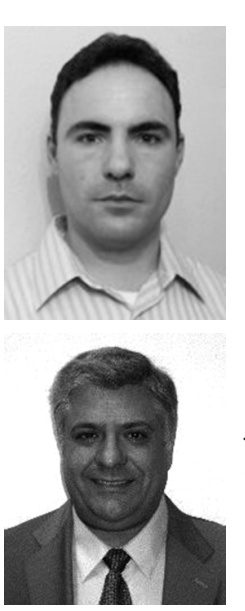

Alejandro Santana Fariña was born in 1981 in Caracas, Venezuela. He studied chemistry and was Assistant Professor in Chemistry at the University Simón Bolivar (Venezuela). He is a Ph.D. student under the supervision of Prof. Dr. José M. G. Molinillo and Prof. Dr. Francisco A. Macias at the University of Cadiz (UCA, Spain). He was awarded a scholarship from UCA, where he works on the synthesis and characterization of bioactive natural products. He completed a research intership at the University of Bristol (UK) in asymmetric synthesis under the supervision of Prof. Dr. Varinder Aggarwal.

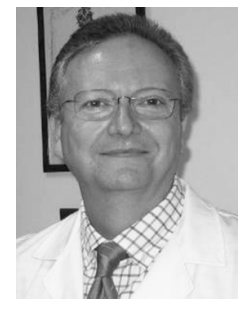

José M.G. Molinillo was born in 1962 in San Fernando (Cádiz), Spain. Since 2010 he has been Professor of Organic Chemistry at the University of Cadiz (Spain). He completed his studies in chemistry in 1985 and obtained his Ph.D. from the University of Cadiz in 1991 with a thesis on the synthesis of natural products. He carried out a postdoctoral project at the University of Tübingen, Germany (1991), where he worked on physiological aspects of allelopathic studies. He conducts research on allelopathy, with a particular emphasis on structure-activity studies, isolation, chemical characterization, and the synthesis of allelopathic agents. He has more than 90 publications, including book chapters, and has co-edited two books on allelopathy.

Francisco A. Macias was born in 1956 in La Linea (Cádiz), Spain. He was a Visiting Associate Professor at the Department of Chemistry at Louisiana State University, Baton Rouge, LA, USA for five years, during which he established a strong collaboration program with Professor Nikolaus H. Fischer in the field of allelopathy. Since 2000 he has been Professor of Organic Chemistry at the University of Cadiz (Spain). He has been honored with the 1999 Rhone-Poulenc Rorer Award, Amsterdam. The Netherlands, from the Phytochemical Society of Europe (PSE) and the 2011 Molish Award, Guangzhou, China, from the International Allelopathy Society (IAS). His research interests concern different aspects of allelopathy, including higher plants and microorganisms, and involve studies on natural and modified ecosystems and the development of new methodologies for allelopathic studies, including mode of action. He heads the "Cadiz Allelopathy Group", which is a pioneer in Europe in allelopathic studies from the organic chemistry viewpoint with a multidisciplinary structure. He is the author of 10 international patents. He has more than 230 publications, including book chapters, has co-edited two books on recent advances in allelopathy, has supervised 23 doctoral theses, and has delivered more than 235 lectures. 
8,12-olide structures. The seco-guaianolides have the least common skeleton of the guaianolides, with a $\mathrm{C}-\mathrm{C}$ single bond broken in one of the rings (Figure 1). Plants that contain such compounds as the active principles have been used in traditional medicine throughout history for the treatment of many diseases. ${ }^{[2]}$ Therefore, it is not surprising that these compounds display an extensive range of biological activities, such as anti-inflammatory, antimicrobial, antiviral, and anti-feedant properties, cytotoxicity against tumor cell lines, fungicidal activity and potential allelopathy among others (Figure 2). Several synthetic strategies have been designed for these compounds because in most cases only small quantities can be isolated from natural sources.
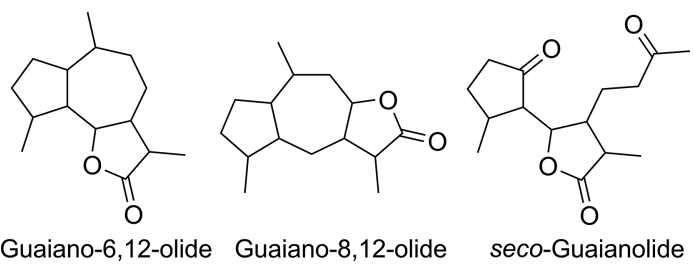

Figure 1. Guaianolide skeletons.

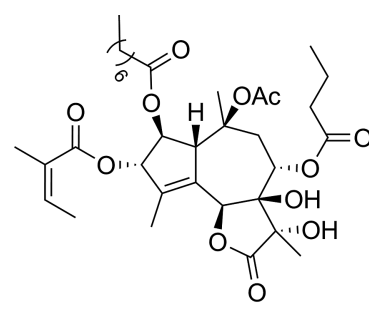

Thapsigargin (1) Potent and selective $\mathrm{Ca}^{2+}$-modulating properties

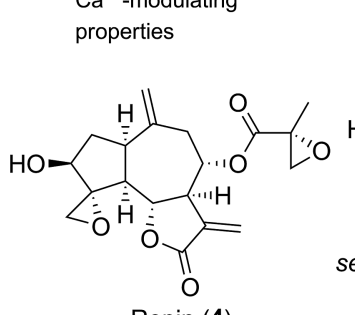

Repin (4)

Potent against cell lines (lung, breast, ovarian and nasopharyngeal cancer), antimicrobial, antiviral

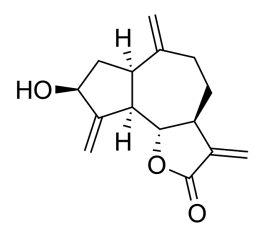

Zaluzanin C (7)

Antimycobacterial, inhibitor against germination and growth of rice

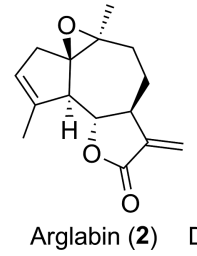

Farnesyl transferase inhibitor

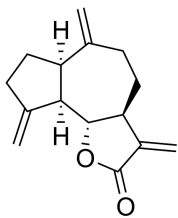

$\mathrm{O}$

Dehydrocostulactone (3)

Suppressor of cytokine signaling (SOCS) proteins, negatively regulate cytokin receptor signaling

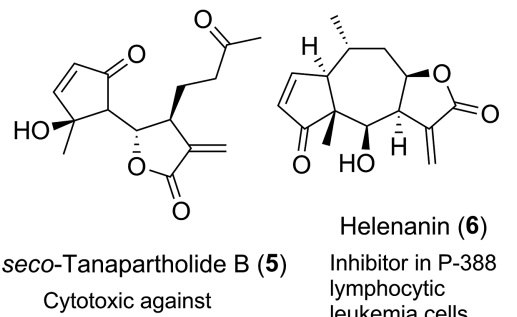

Figure 2. Structural diversity of guaianolides and their importance as bioactive molecules.

Many guaianolides and seco-guaianolides contain an $\alpha$ methylene butyrolactone system, a privileged moiety that is

present in $10 \%$ of all natural products. ${ }^{[3]}$ It is well known that the alkylating properties, and hence the potential tumor-inhibiting abilities, of these sesquiterpene $\gamma$-lactones arise from Michael-type interaction between the $\alpha, \beta$-unsaturated exomethylene lactone moiety and the nucleophilic cellular components. Extensive research has been carried out to characterize the molecular mechanisms of the anticancer activities of these compounds and their potential use as chemopreventive and chemotherapeutic agents. Both the cytotoxicity and the anti-inflammatory properties of SLs are mediated by the $\alpha, \beta$-unsaturated carbonyl functions, such as cyclopentenone and the $\alpha$-methylene $\gamma$-lactone moiety. The former unit seems to be slightly more associated with cytotoxicity, whereas the latter is believed to be the major group that mediates the anti-inflammatory activity of SLs. ${ }^{[4]}$ The bioactivity has also been attributed to other factors, such as the lipophilicity of a molecule and its geometry. ${ }^{[5]}$

These natural products provide a rich source of biologically validated small-molecule scaffolds that fit the philosophy of biology-oriented synthesis. Indeed, guaianolides can serve as excellent leads for drug development and have been synthetic targets for more than four decades. Nevertheless, molecular complexity can pose formidable synthetic challenges. Numerous methodologies have been described, and these can be classified into two main groups: total synthesis in cases in which the construction of the guaianolide skeleton involves the use of readily available small molecules as starting materials, and hemi-synthesis or semi-synthesis when the strategy involves a structurally complex molecule or an isolated natural compound, usually a eudesmane or germacrane sesquiterpene.

Sesquiterpene lactones and guaianolides have been extensively reviewed in the literature. ${ }^{[1,6,7,8]}$ The aim of this microreview is to provide the interested reader with a summary of the most relevant synthetic strategies and an update of the latest developments in the synthesis of these fundamental compounds.

\section{Semi-Synthesis}

Semi-synthesis is usually used when the precursor molecule is structurally too complex or too costly, or if its production by total synthesis is too inefficient in terms of yield.

In guaianolide chemistry, the use of some eudesmane or guaiane sesquiterpenoids has always been a common approach (Figure 3). The ubiquitous nature and the structural simplicity of these systems are thought to be very closely related. The majority of the strategies involve isomerization

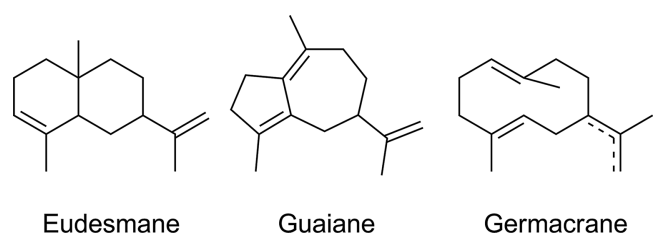

Figure 3. Sesquiterpenoid skeletons. 
(including photoisomerization), solvolysis, or rearrangement of the sesquiterpenoid to obtain the desired skeleton. It is also common practice to functionalize a readily available skeleton to generate new products.

Despite the developments in total synthesis, semi-synthesis is still a useful tool and is sometimes more effective for obtaining a prodrug with promising biological activity, especially if the starting materials are readily available. In the following sections the key and latest strategies are discussed according to the type of skeleton used as the starting material.

\section{Guaianolide Strategies}

The simplest strategy starts with a molecule that already contains the guaianolide skeleton, which is modified to obtain the desired products.

Dehydrocostuslactone (DHC, 3, Figure 2), first synthesized by Rigby et al. in $1984,{ }^{[9]}$ has been used as a starting material because it is readily available from crude costus resin oil (Saussurea lappa) by column chromatography (CC). The use of DHC for the generation of synthetic guaianolide-type derivatives and the biological activities of the resulting compounds have been reported. In particular, in 1984 Kalsi et al. ${ }^{[10]}$ used DHC and isozaluzanin C to synthesize twenty new derivatives each with an exocyclic methylene group at C-4 conjugated with a C-3 ketone. These compounds were tested as plant growth regulators.

A DHC derivative named subexpinnatin, previously isolated by Massanet and co-workers in 1982, ${ }^{[11]}$ was used by the same group in 1987 after saponification in a regio- and stereoselective chemical transformation to yield the natural oxetane lactone subexpinnatin C (13).$^{[12]}$ This transformation involves a photocycloaddition reaction between the $\alpha$ methylene $\gamma$-lactone 9 and acetaldehyde as a new method to obtain the oxetane ring (Scheme 1). Five years later the same group reported the synthesis of natural SLs soulangianolide A,melampomagnolides Aand B,zaluzanin Candisozaluzanin $\mathrm{C}$ from DHC, costunolide, and parthenolide by use of $\mathrm{SeO}_{2}$ and $t \mathrm{BuOOH} .{ }^{[13]}$

In 2000, Macías et al. completed an intensive structureactivity study directed towards evaluating the effects of fifteen guaianolide derivatives obtained from DHC (3) on the growth and germination of several mono- and dycotyledon target species (Figure 4, Table 1). ${ }^{[13,14]}$

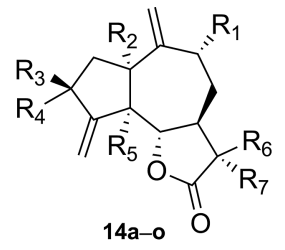

Dehydrocostuslactone

$\left(\mathrm{R}_{1-5}=\mathrm{H}, \mathrm{R}_{6-7}=\mathrm{CH}_{2}\right)(3)$

Figure 4. Guaianolides tested (see also Table 1).

Table 1. Guaianolides tested by Macías et al.

\begin{tabular}{llllllll}
\hline & $\mathrm{R}_{1}$ & $\mathrm{R}_{2}$ & $\mathrm{R}_{3}$ & $\mathrm{R}_{4}$ & $\mathrm{R}_{5}$ & $\mathrm{R}_{6}$ & \multicolumn{2}{c}{$\mathrm{R}_{7}$} \\
\hline $\mathbf{a}$ & $\mathrm{H}$ & $\mathrm{H}$ & $\mathrm{H}$ & $\mathrm{OH}$ & $\mathrm{H}$ & & $-\mathrm{CH}_{2}-$ \\
$\mathbf{b}$ & $\mathrm{H}$ & $\mathrm{H}$ & $\mathrm{OH}$ & $\mathrm{H}$ & $\mathrm{H}$ & & $-\mathrm{CH}_{2}-$ \\
$\mathbf{c}$ & $\mathrm{H}$ & $\mathrm{H}$ & $\mathrm{H}$ & $\mathrm{H}$ & $\mathrm{OH}$ & & $-\mathrm{CH}_{2}-$ \\
$\mathbf{d}$ & $\mathrm{H}$ & $\mathrm{H}$ & $\mathrm{H}$ & $\mathrm{OH}$ & $\mathrm{OH}$ & \multicolumn{2}{c}{$-\mathrm{CH}_{2}-$} \\
$\mathbf{e}$ & $\mathrm{H}$ & $\mathrm{OH}$ & $\mathrm{H}$ & $\mathrm{OH}$ & $\mathrm{OH}$ & \multicolumn{2}{c}{$-\mathrm{CH}_{2}-$} \\
$\mathbf{f}$ & $\mathrm{OH}$ & $\mathrm{H}$ & $\mathrm{H}$ & $\mathrm{OH}$ & $\mathrm{OH}$ & \multicolumn{2}{c}{$-\mathrm{CH}_{2}-$} \\
$\mathbf{g}$ & $\mathrm{H}$ & $\mathrm{H}$ & & $-\mathrm{O}-$ & $\mathrm{H}$ & \multicolumn{2}{c}{$-\mathrm{CH}_{2}-$} \\
$\mathbf{h}$ & $\mathrm{H}$ & $\mathrm{H}$ & $\mathrm{H}$ & $\mathrm{H}$ & $\mathrm{H}$ & $\mathrm{CH}_{2} \mathrm{O} \mathrm{H}^{-}$ \\
$\mathbf{i}$ & $\mathrm{H}$ & $\mathrm{H}$ & $\mathrm{H}$ & $\mathrm{H}$ & $\mathrm{H}$ & $\mathrm{H}$ & $\mathrm{CH}_{2} \mathrm{O}$ \\
$\mathbf{j}$ & $\mathrm{H}$ & $\mathrm{H}$ & $\mathrm{H}$ & $\mathrm{H}$ & $\mathrm{H}$ & $\mathrm{CH}$ & $\mathrm{OH}$ \\
$\mathbf{k}$ & $\mathrm{H}$ & $\mathrm{H}$ & $\mathrm{H}$ & $\mathrm{OH}$ & $\mathrm{H}$ & $\mathrm{H}$ & $\mathrm{CH}_{2} \mathrm{O}$ \\
$\mathbf{l}$ & $\mathrm{H}$ & $\mathrm{H}$ & $\mathrm{H}$ & $\mathrm{OH}$ & $\mathrm{OH}$ & $\mathrm{H}$ & $\mathrm{CH}_{2} \mathrm{O}$ \\
$\mathbf{m}$ & $\mathrm{H}$ & $\mathrm{H}$ & $\mathrm{H}$ & $\mathrm{H}$ & $\mathrm{OH}$ & $\mathrm{H}$ & $\mathrm{CH}_{2} \mathrm{O}$ \\
$\mathbf{n}$ & $\mathrm{H}$ & $\mathrm{H}$ & $\mathrm{H}$ & $\mathrm{OH}$ & $\mathrm{OH}$ & $\mathrm{H}$ & $\mathrm{CH}_{3}$ \\
$\mathbf{o}$ & $\mathrm{H}$ & $\mathrm{OH}$ & $\mathrm{H}$ & $\mathrm{OH}$ & $\mathrm{OH}$ & $\mathrm{H}$ & $\mathrm{CH}_{3}$ \\
\hline
\end{tabular}

In 2013, Chen and co-workers ${ }^{[15]}$ reported the application of the Heck reaction in the synthesis of guaianolide sesquiterpene lactone derivatives that selectively inhibited resistant acute leukemic cells. Under standard Heck reaction conditions, a series of SLs were obtained from DHC (3) and micheliolide (15) after arylation of the $\alpha$-methylene$\gamma$-lactone moiety (Scheme 2). In the case of micheleolide it was essential to protect the hydroxy group at the C-3 position.

Grossheimin, cynaropicrin, arglabin, estafiatin, ludartin, achillin, grossmisin, and artefin are other guaianolide lactones that have been widely functionalized to obtain a series of structural derivatives of both chemical and biological interest. Several derivatives of these lactones have been re-

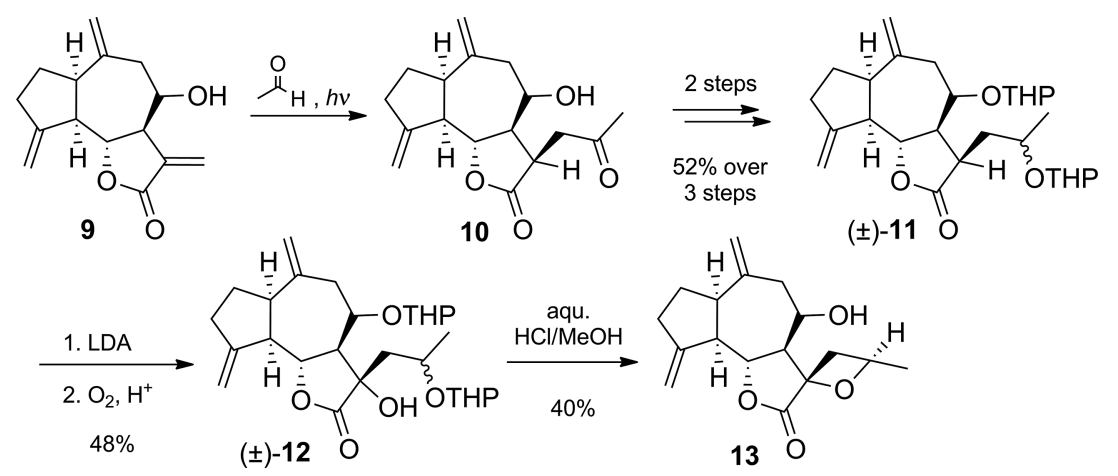

Scheme 1. Synthesis of oxetane lactone subexpinnatin C. 


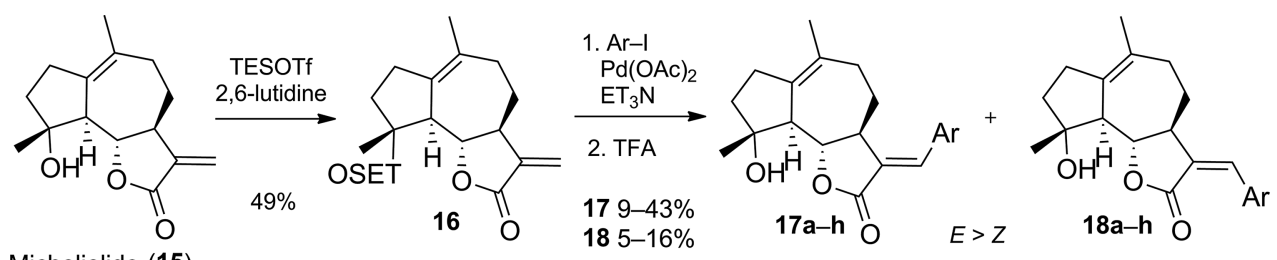

Micheliolide (15)

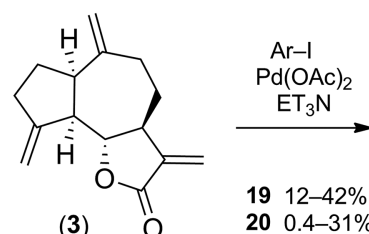

Dehydrocostuslactone
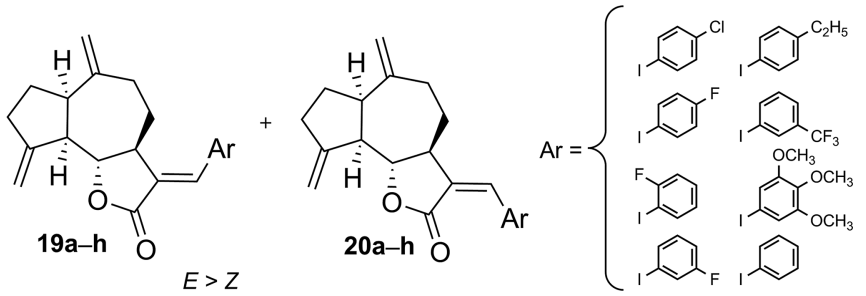

Scheme 2. Application of Heck reactions in the synthesis of guaianolides.

ported in the last decade by Raldugin, Adekenov, and coworkers. ${ }^{[16]}$ All of these methodologies led to new structures that were usually established by X-ray crystal analyses. Among them it is important to note the generation of chloro derivatives of grossmisin and achillin by treatment with chlorine, of dinitro derivatives of achillin and grossmisin from a one-step synthesis with gaseous $\mathrm{NOCl}$, of dialkyl phosphonate derivatives of arglabin and grossheimin by use of sodium dimethyl and diethyl phosphonates, of a pentachloro derivative and a new dichlorocarbene derivative from arglabin and estafiatin obtained in the presence of a crown ether, and of halohydrins of ludartin by use of $\mathrm{LiCl}$ in the presence of $\mathrm{CH}_{3} \mathrm{CO}_{2} \mathrm{H}$ (Figure 5).

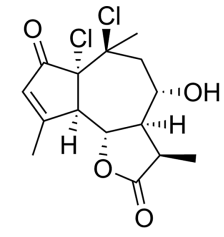

Dichloro-grossmisin (21)

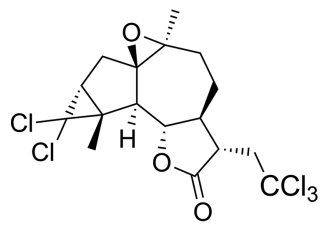

Pentachloro-arglabin (24)

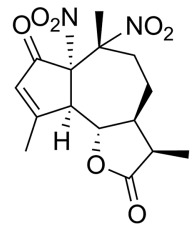

Dinitro-achillin (22)

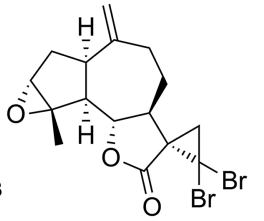

Dibromocarbene-estafiatin (25)

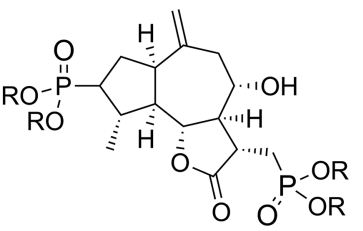

(23)
Figure 5. Some of the guaianolide derivatives obtained by Adek-

Furthermore, in 1989 Barbetti and co-workers synthesized a sequence of 13-phenylseleno derivatives of guaianolides from grossheimin (27) and cynaropicrin (28); these compounds showed cytotoxic activity against $\kappa \mathrm{B}$ cell cultures. ${ }^{[17]}$ In 2012 Csuk et al. synthesized several derivatives of arglabin obtained by extraction, including modifications on the endocyclic double bond. Arborescin (30) was generated from arglabin (2) by hydrogenation. ${ }^{[18]}$ Bhat et al. also enov and co-workers. obtained amino analogues of ludartin (31), a potent and selective cytotoxic agent, ${ }^{[19]}$ by use of a Michael addition at the exocyclic double bond of the $\alpha$-methylene $\gamma$-lactone as a key step (Scheme 3).

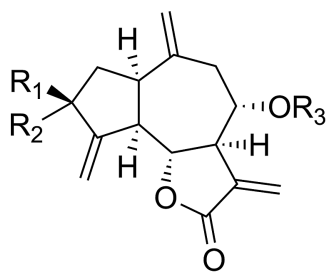

Grossheimin (27): $\mathrm{R}_{1}=\mathrm{R}_{2}=\mathrm{O}, \mathrm{R}_{3}=\mathrm{H}$ Cynaropicrin (28): $\mathrm{R}_{1}=\mathrm{OH}, \mathrm{R}_{2}=\mathrm{H}$, $\mathrm{R}_{3}=\mathrm{COC}\left(\mathrm{CH}_{2}\right) \mathrm{COH}$

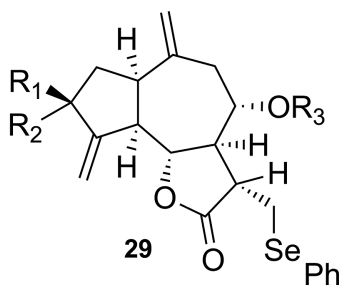

seleno derivatives<smiles>C=C1C(=O)O[C@H]2C1CC[C@@]1(C)O[C@]21CC=C(C)C</smiles>

Arglabin (2)

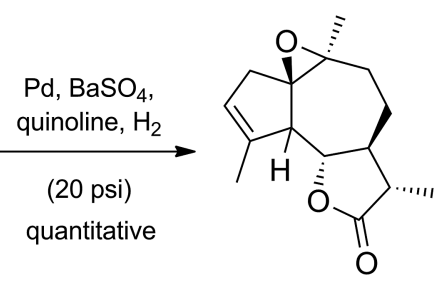

Arborescin(30)

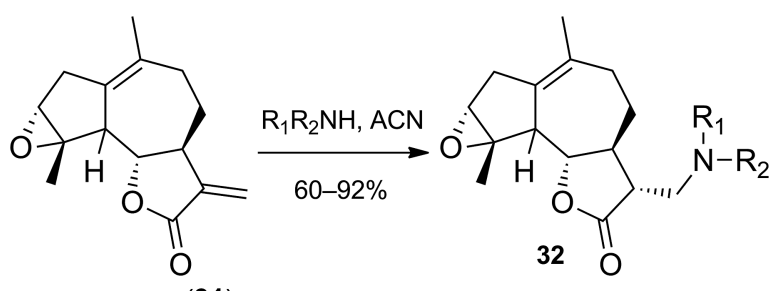

Ludartin (31)

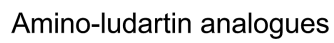

Scheme 3. Synthesis of guaianolide derivatives.

Less common guaianolides have been used in the synthesis of several derivatives with fascinating structural diversity. In 1972 Shafizadeh and Bhadane synthesized viscidulin B from the known guaianolide cumambrin B, previously isolated from Artemisia nova Nels. ${ }^{[20]}$ In 1992 Giordano and co-workers reported the reduction and acetylation of dehydroleucodin, helenalin, hymetin, mexicanin I, 
and ludartin guaiane lactones as part of a structure-activity relationship study on the gastric cytoprotective effect of several guaianolides. ${ }^{[21]}$ In 2005 Bruno et al. identified activity against tumor cell replication in several synthetic guaianolide derivatives of repsin. ${ }^{[22]}$

\section{Germacranolide Strategies}

Germacranolides, biogenetic precursors of guaianolides, have frequently been used as starting materials in their synthesis.

In 1980 González et al. carried out a biomimetic cyclization of gallicin, isolated from Artemisia maritima gallica ssp. Willd, to yield guaianolides. ${ }^{[23]}$ In 1988 the same group prepared melampomagnolide B (34, Scheme 4) and its 11,13dihydro derivative from parthenolide (33) by allylic oxidation with $\mathrm{SeO}_{2} / \mathrm{HOO} t \mathrm{Bu}$, followed by $\mathrm{NaBH}_{4}$ reduction and then conversion into guaianolides through biomimetic cyclization. ${ }^{[24]}$ Melampomagnolide B and its 11,13-dihydro derivative were converted to epimeric trans-guaianolides $\mathbf{3 5}$ by acid treatment. The same group also reported the biomimetic synthesis of $5 \alpha$-hydroxyguaianolides from vulgarin. ${ }^{[25]}$ In 1989 Bordoloi and co-workers described the reaction of tagitinin $\mathrm{C}$, isolated from Tithonia diversifolia, with $\mathrm{SnCl}_{2}$ to produce cyclotagitinin $\mathrm{C}$, a guaianolide that can be biomimetically transformed into pseudoguaianolides. ${ }^{[26]}$

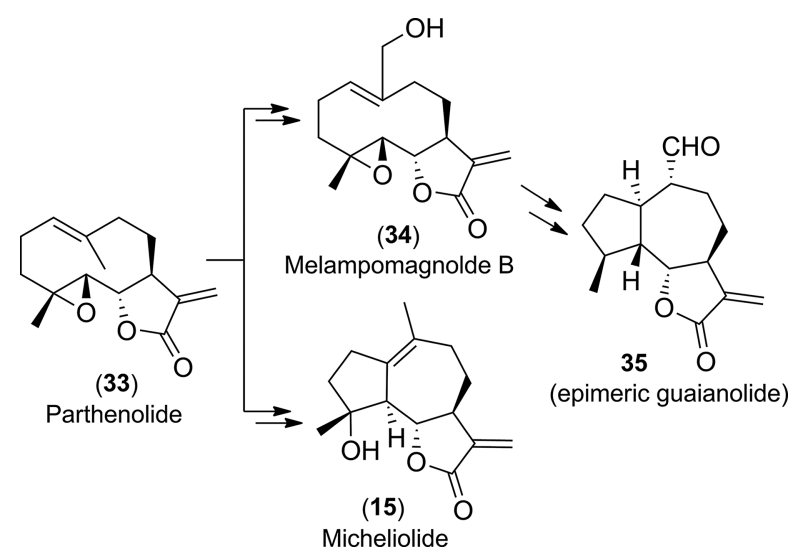

Scheme 4. Germacranolide strategies based on 33.

In 1993 Fischer et al. reported the biomimetic transformation of parthenolide (33), isolated from Magnolia grandiflora $\mathrm{L}$., by use of $\mathrm{BF}_{3}$-mediated rearrangement to yield guaianolides and seco-guaianolides, such as micheliolide (15, Scheme 4). ${ }^{[27]}$ In an extension of the work of Fischer et al., in 2012 Chen, Gao, and co-workers generated a series of guaianolides by use of parthenolide as the starting material. These guaianolides are particularly interesting because they can selectively eradicate acute myelogenous leukemia (AML) stems or progenitor cells. ${ }^{[28]}$

In 2008, Massanet and co-workers reported the synthesis of some guaianolides and germacranolides from costunolide (36), which is readily available from the roots of Sauss- urea lappa. ${ }^{[29]}$ This study demonstrated that conformational changes in the structures of germacranolides can be induced by placing an oxygenated functionality at carbon C6 with the appropriate orientation. The methodology described is suitable for the preparation of eudesmanolides and guaianolides found in umbelliferous plants (Scheme 5).

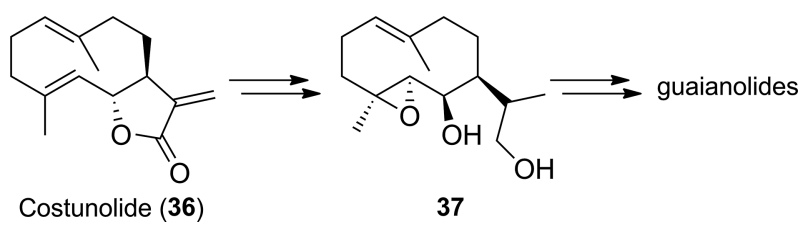

Scheme 5. Germacranolide strategies based on $\mathbf{3 6}$.

\section{Eudesmanolide Strategies}

$(-)-\alpha-$ Santonin (38, Scheme 6$)$ is the most important and widely used compound for the synthesis of guaianolides. Compound $\mathbf{3 8}$ is an abundant eudesmanolide that has been isolated from the genus Artemisia (especially from Artemisia maritime, A. cina, or A. chamaemelifolia). Santonin exists as colorless flat prisms that turn pale yellow due to the action of light. $8 \alpha$-Hydroxysantonin, named artemisin, is also found in these plants, although it is less abundant. ${ }^{[30]}$ $(-)-\alpha$-Santonin is also commercially available and can be readily functionalized. This eudesmanolide lactone contains an A-ring with a cross-conjugated dienone system and a lactone moiety, which makes it very interesting as a starting material for the synthesis of a variety of compounds with promising biological importance, especially those with eudesmane, guaiane, and elemane skeletons. ${ }^{[26]}$

The transformation of santonin (38) into guaianolides has been carried out by two different methods: the photochemical rearrangement of the dienone system present in the A-ring of santonin and the solvolytic rearrangement of an appropriate 1-sulfonate derivative (Scheme 6). Irradiation of santonin with UV light in $\mathrm{AcOH}$ solution is a photochemical process that has been known since 1957 to provide guaianolides such as $O$-acetylisophotosantonic lactone (40). ${ }^{[31]}$ This transformation is the initial step in several recent syntheses of guaianolides and related compounds and has been described as a single-crystal-to-single-crystal reaction. ${ }^{[32]}$

$O$-Acetylisophotosantonic lactone (40) was used by Marx and White in 1969 for the synthesis of achillin (46) after epimerization at C-1. ${ }^{[33]}$ In 1976 Winter and Lindauer also used this compound in the synthesis of photunolide (50) in order to corroborate the structure and stereochemistry of the product obtained by photoisomerization of the germacranolide dihydrocostunolide, which proceeded with a high degree of regio- and stereoselectivity (Scheme 7). ${ }^{[34]}$ In addition, in 1986 Sharma and co-workers described the biomimetic transformation of isophotosantonic lactone into pseudoguaianolides. ${ }^{[35]}$ 


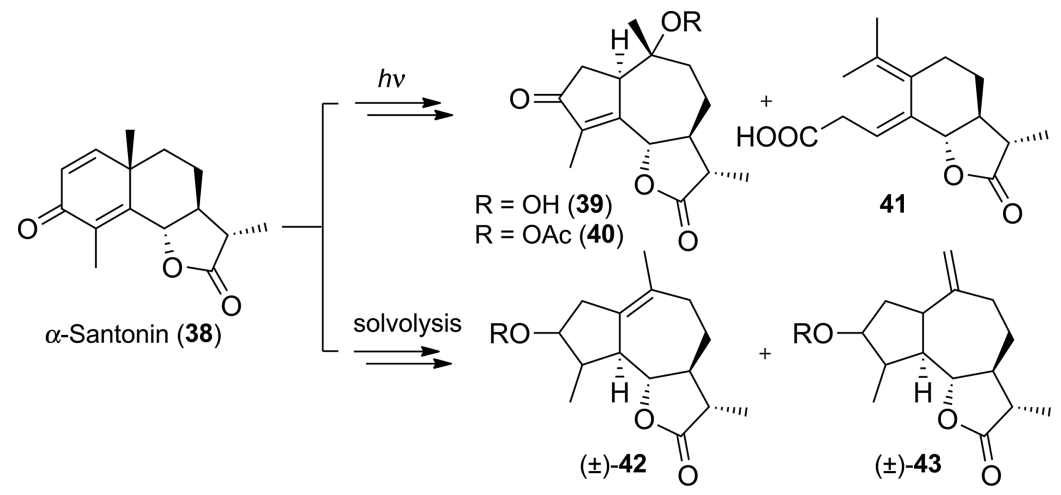

Scheme 6. Transformation of $\alpha$-santonin into guaianolides.

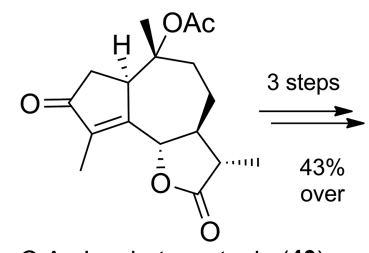

O-Ac-Isophotosantonin (40) $\mathrm{H}_{2}, \mathrm{Pd} / \mathrm{C} \downarrow \mathrm{HOAC}$

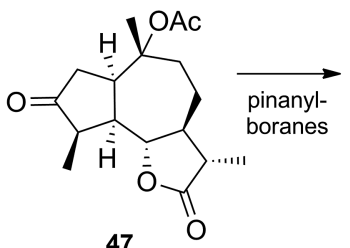

47

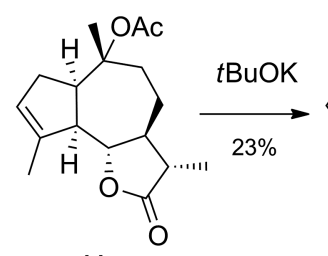

44

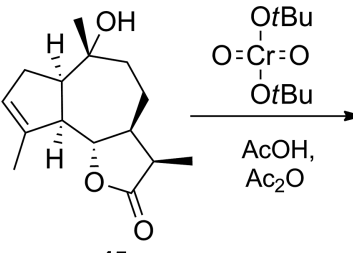

45

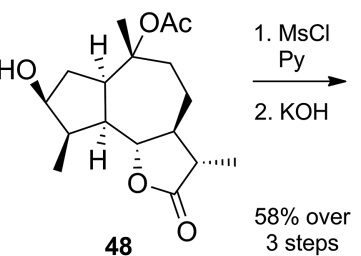

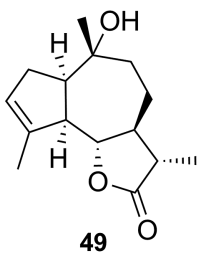

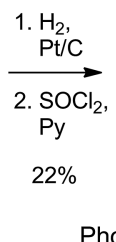

Scheme 7. Syntheses of achillin and photunolide.

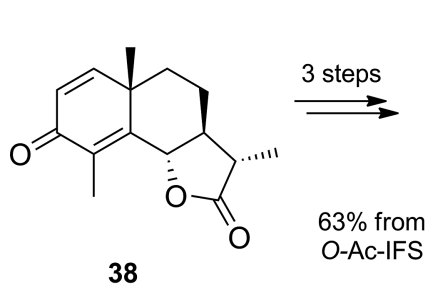

38

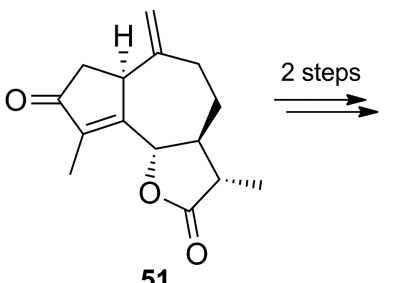

51

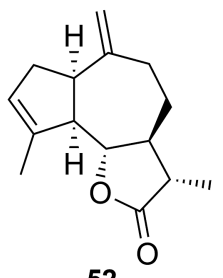

52
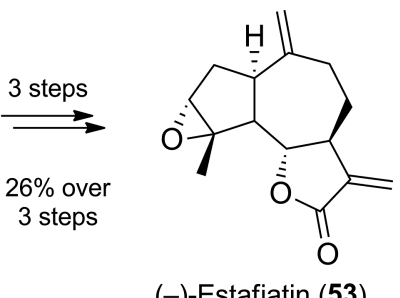

(-)-Estafiatin (53)

Scheme 8. Synthesis of (-)-estafiatin.

In 1979 Greene, Crabbé, and co-workers reported the stereoselective synthesis of (-)-estafiatin (53) from $\alpha$-santonin (38). ${ }^{[36]}$ The key intermediate in the synthesis was the trisubstituted olefin, which was obtained as a mixture of tri- and disubstituted olefins by high-temperature dehydration in hexamethylphosphoric triamide, with the mixture separated on silver-nitrate-impregnated silica gel (Scheme 8).

Ando et al. described a significant synthetic study in which several natural sesquiterpene guaianolides or derivatives were obtained by use of $\alpha$-santonin as the starting material. ${ }^{[37]}$ It is important to mention the syntheses of arborescin (30), 1,10-epi-arborescin, and the trisubstituted olefin that served as the key intermediate in Greene and Crabbé's synthesis of estafiatin. This route included as a key step the solvolytic rearrangement of a mesyloxy-eudesmano lactone. ${ }^{[38]}$ This methodology was also applied in the synthesis of zaluzanins C and D, 3-epi-zaluzanin C, Mokko lactone, DHC, eremathin, ludartin, leucodin, kaunolide, arborescin, and other related compounds (Scheme 9).

A similar synthetic strategy was presented by Pedro and co-workers for the stereoselective synthesis of $4 \alpha$-hydroxy8,12-guaianolides, 3-oxa-guaianolides, and dihydroestafiatin, dihydroludartin, (-)-compressanolide, and dihydromicheliolide. ${ }^{[39]}$ This approach was also used by Barbosa et al. in the synthesis of new $\alpha$-santonin derivatives. ${ }^{[40]}$ 


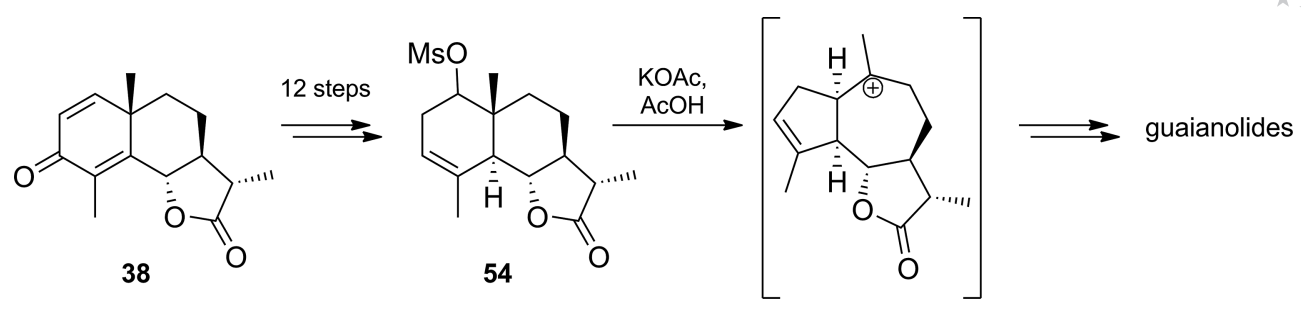

Scheme 9. Key step in the synthesis of guaianolides.<smiles>CC1=C2C=CC(=O)C=C2CCC1[C@H](C)C(=O)O</smiles>

$\alpha$-Santonin (38)

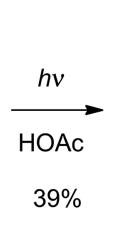

$39 \%$

$$
\text { O-Ac-Isophotosantonin (40) }
$$

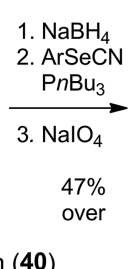

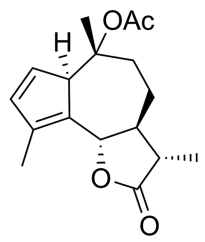

55
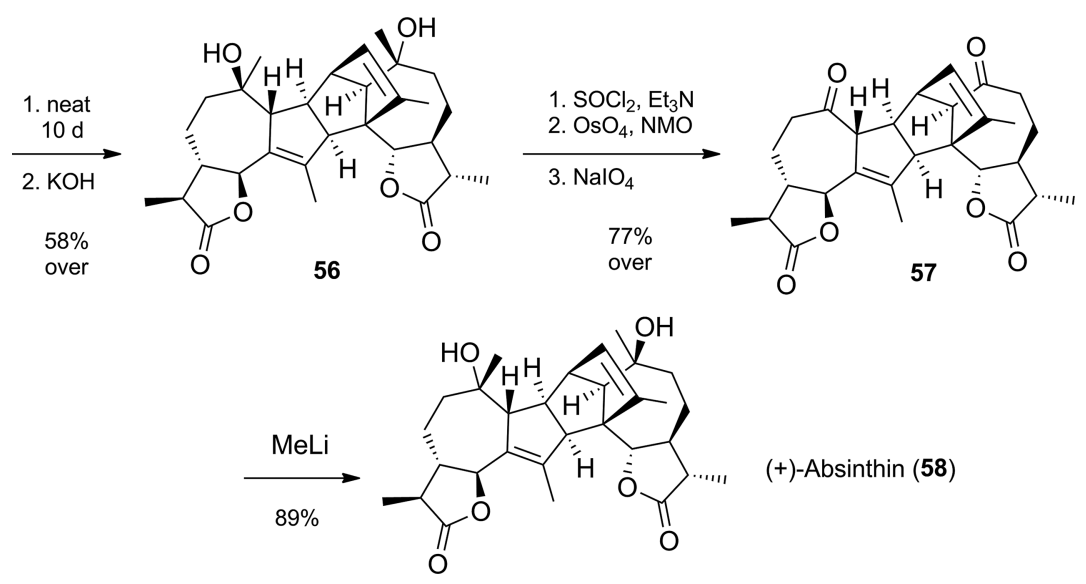

(+)-Absinthin (58)

Scheme 10. Synthesis of (+)-absinthin.

An efficient methodology was reported by Zhai and coworkers in 2004 for the synthesis of (+)-absinthin (58) from $\alpha$-santonin (38) in ten steps. ${ }^{[41]}(+)$-Absinthin was isolated in 1953 by Herout as the main dimeric guaianolide from wormwood Artemisia absinthium L. ${ }^{[42]}$ The first step of the synthetic strategy was the generation of $O$-acetylisophotosantonin (40), which after nine steps yielded the desired natural product in 19\% overall yield (Scheme 10).

In 2012 Lei et al. described the first biomimetic synthesis of (-)-gochnatiolides A-C and (-)-ainsliadimer B, based on their proposed biogenetic pathway. ${ }^{[43]}$ The main features of the synthesis are one-pot cascade transformations including Saegusa oxidation, intermolecular Diels-Alder cycloaddition, and radical-mediated allylic oxidation, which allow the rapid generation of products in a collective manner. A biomimetic transformation from gochnatiolide B (61) to ainsliadimer B (62) was achieved through a direct enone hydration. Dehydrozaluzanin C (59), prepared in 11 steps from $\alpha$-santonin, was used as a common precursor (Scheme 11). In 2013 Qin and co-workers also reported the synthesis of ainsliadimer B and gochnatiolides A and B. ${ }^{[44]}$
The key step in the route was a cross-Diels-Alder cycloaddition of a modified dehydrozaluzanin $\mathrm{C}$ that allowed the highly regio- and stereoselective assembly of the skeletons.

In the last decade, seco-guaianolides have attracted a great deal of attention in the continued search for bioactive compounds that can act as leads for drug discovery or as tools for biological studies. In 2009 Hay, Westwood, and co-workers reported the isolation, synthesis, and biological evaluation of iso-seco-tanapartholides 68 and $69 .{ }^{[45]} \mathrm{A}$ key step was the late-stage oxidative cleavage reaction, which was carried out in the absence of protecting groups to give the natural products directly (Scheme 12). The study also showed that the synthetic derivatives of the seco-guaianolides were indeed inhibitors of the NF- $\mathrm{kB}$ signaling pathway.

In 2012 Macías et al. described a facile procedure for the preparation of bioactive seco-guaianolide and of other guaianolides. ${ }^{[46]}$ There are two key steps in this interesting synthetic strategy. A high-yielding photochemical reaction, optimized through an extensive study of the reaction conditions, revealed that isophotosantonin (39) can be obtained as the main product and in high yields by judicious choice 
<smiles>C=CC(C)C</smiles>

$\alpha$-Santonin (38)<smiles>C=C1CCC2C(=C)C(=O)O[C@@H]2C2C(=C)C(=O)CC12</smiles>

Dehydrozaluzanin C (59)<smiles>C=C1CCC2C(=C)C(=O)O[C@@H]2C2C(=O)C(OC)=CC12</smiles>

60

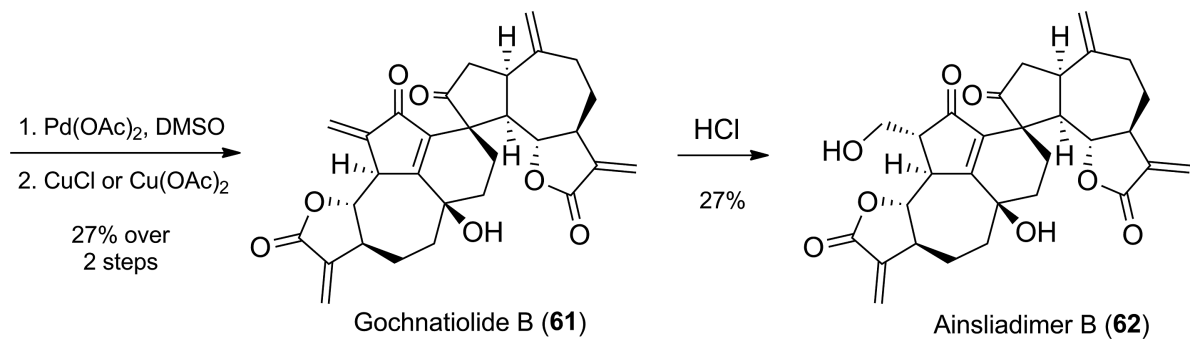

Scheme 11. Syntheses of (-)-gochnatiolides A-C and (-)-ainsliadimer B.
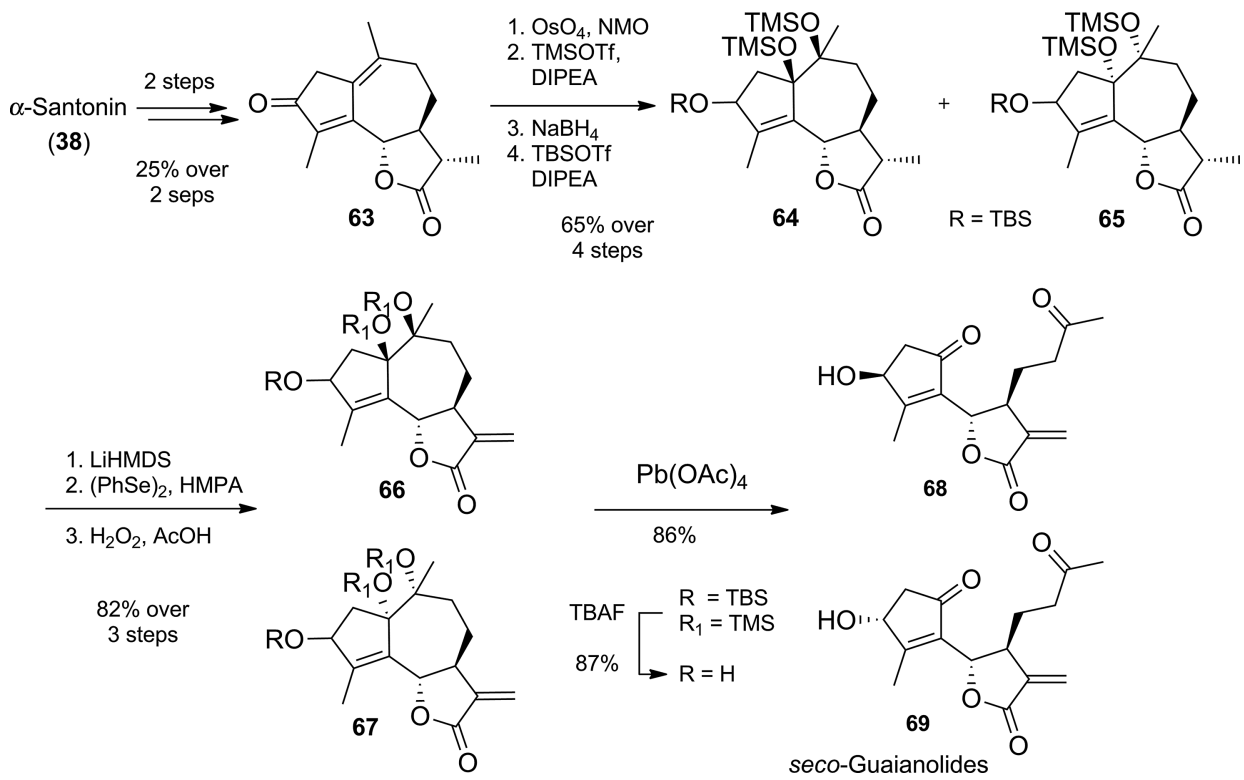

4 steps

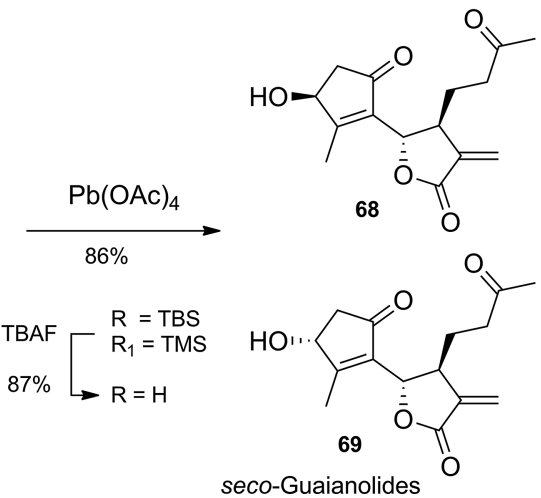

Scheme 12. Synthesis of iso-seco-tanapatholides.

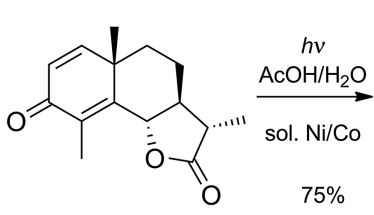

$\alpha$-Santonin (38)<smiles>CC1=C2CC(=O)C(C)=C2[C@H]2OC(=O)[C@H](C)[C@@H]2CC1</smiles>

1 or 2 steps

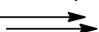

Isophotosantonin (39)<smiles>CC(=O)CC[C@H]1C(C2=C(C)C(=O)CC2=O)OC(=O)[C@H]1C</smiles>

seco-Guaianolide

Guaianolides

of conditions. Furthermore, oxidation with ozone to cleave the $\mathrm{C}=\mathrm{C}$ bond to give ketones provided the highly oxygenated and active seco-guaianolide 70 (Scheme 13).

\section{Total Synthesis}

Interest in hydroazulenic lactones (5,7-ring) has increased steadily over the past four decades, given the useful properties of these compounds. Although several synthetic strategies have been proposed, only a very few have been successful for the synthesis of pseudoguaianolides, particu-

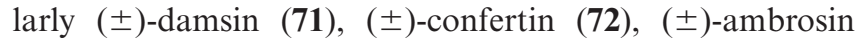
(73), ( \pm )-psilostachyin C (74), and ( \pm )-aromatin (75, Figure 6). ${ }^{[4]}$ Several methodologies have been developed and these can be separated according to the proposed synthetic strategy. A summary of these strategies and recent methods is provided below.

Scheme 13. Synthesis of seco-guaianolide and of other guaianolides. 


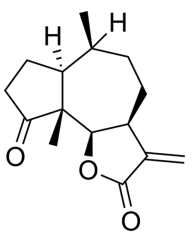

( \pm )-Damsin (71)

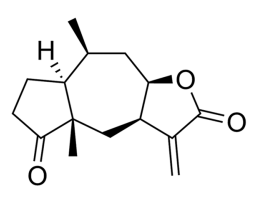

( \pm )-Confertin (72)

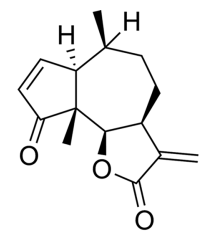

( \pm )-Ambrosin (73)

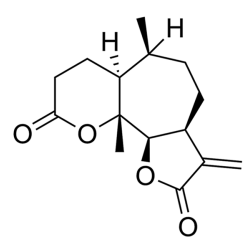

(士)-Psilostachyin C (74)

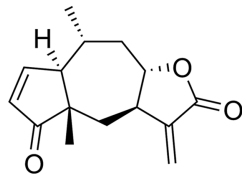

( \pm )-Aromatin (75)
Figure 6. Early pseudoguaianolide target compounds.

\section{Hydroazulene Strategies by Ring Enlargement or Rearrangement}

The use of rearrangement reactions aside, most of the synthetic strategies for such hydroazulenes (also named bicyclo[5.3.0]decanes) start with a five-membered ring compound, and the seven-membered ring is elaborated by ring enlargement or isomerization reactions ${ }^{[48]}$ followed by lactone ring formation.

The 1983 publications by Vandewalle et al. (described in the next section) ${ }^{[49]}$ largely concern the first total synthesis of the guaianolides $( \pm)$-compressanolide and $( \pm)$-estafiatin. Nevertheless, to the best of our knowledge, the first synthesis of the 4,5-epoxyosmitopsin family, starting from cyclohexane-1,3-dione, was reported in 1980 by Posner. This was the first, highly stereocontrolled, total synthesis of an $\alpha$ methylene-substituted guaianolide, although it is not a natural product (Scheme 14).${ }^{[50]}$ In this synthesis two of the six chiral centers were introduced stereoselectively and the other four were introduced with virtually complete stereocontrol. This methodology starts with a Michael addition of cyclohexane-1,3-dione (76) to methyl vinyl ketone, followed directly by sodium borohydride reduction to obtain a cyclic enol ether. The octalone $\mathbf{8 1}$ was subsequently obtained as a precursor of hydroazulenone, which itself would be an intermediate for the preparation of epoxyguaianolide $\mathbf{8 5}$.

Rigby et al. reported the total synthesis of two guaianolides - ( \pm )-dehydrocostuslactone (3) and ( \pm )-estafiatin (53) - and later of ( \pm )-grosshemin (27). ${ }^{[51,9]}$ The methodology used the cis-fused hydroazulenic intermediates derived from tropone $\mathbf{8 6}$ through "conjugate" 1,8-addition of the Grignard reagent derived from 2-(2-bromoethyl)-1,3-dioxolane through an unusual Lewis acid olefin cyclization. The ( \pm )-dehydrocostuslactone was synthesized in twelve steps, and ( \pm )-estafiatin was obtained in two more steps (Scheme 15). ( \pm )-Grosshemin was synthesized three years later by a similar methodology. ${ }^{[52]}$

An interesting and convenient methodology reported by Lee in 1997 includes a radical cyclization to achieve the total synthesis of (+)-cladantholide (102) and (-)-estafiatin (53). ${ }^{[53]}$ Starting from commercially available $(R)-(-)$-carvone (94), the highly substituted cyclopentane 97 (Scheme 16) was prepared in a four-step sequence ${ }^{[54]}$ based on epoxidation of the enone, regioselective epoxide opening, and a Favorskii rearrangement that resulted in ring contraction to a cyclopentanecarboxylate. This is an excellent strategy that leads to the cyclopentanecarboxylate $\mathbf{9 7}$, which can be modified and used as a precursor in numerous reactions. The bromoacetal 95 was obtained in three further steps, and this was subjected to standard high-dilution radical-generating conditions with $\mathrm{AIBN} / \mathrm{Bu}_{3} \mathrm{SnH}$ to give the hydroazulenic acetal. The final keto-lactone was prepared by radical cyclization through THP removal and Jones oxidation.

In a huge synthetic study, Ley et al. developed the total synthesis of several members of the thapsigargin family and
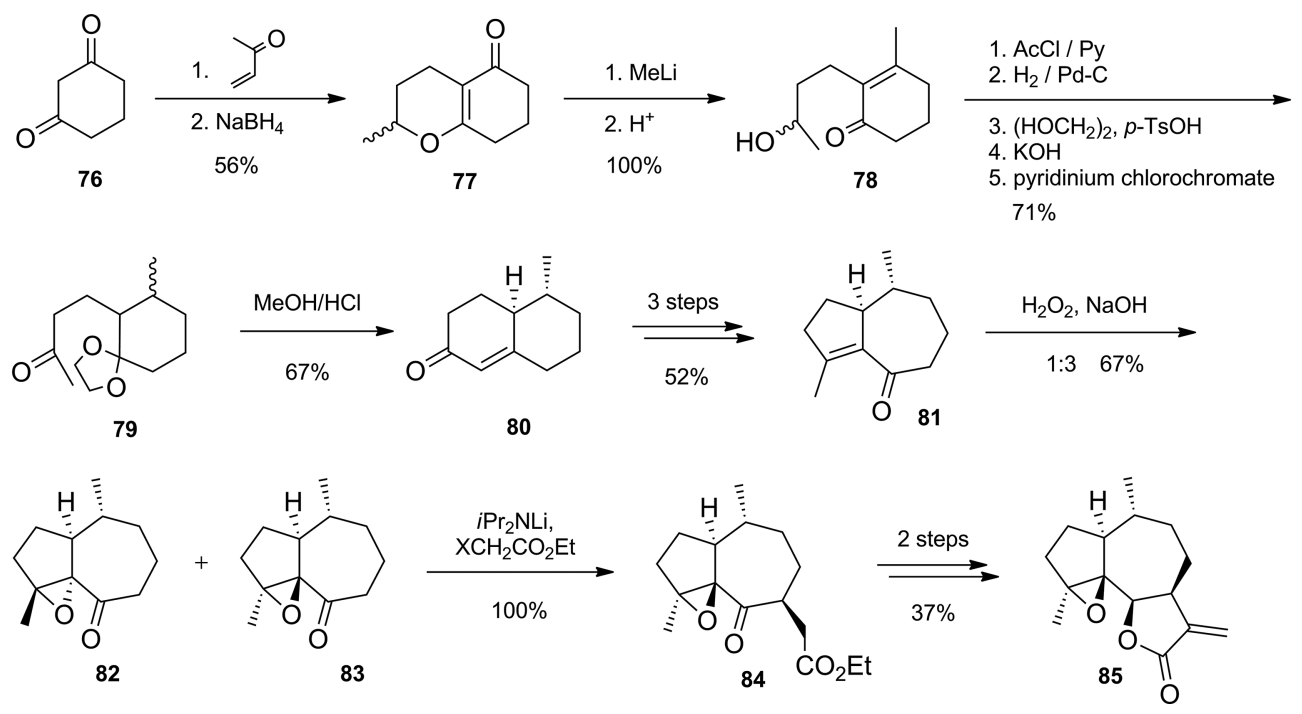

Scheme 14. Synthesis of the 4,5-epoxyosmitopsin family. 

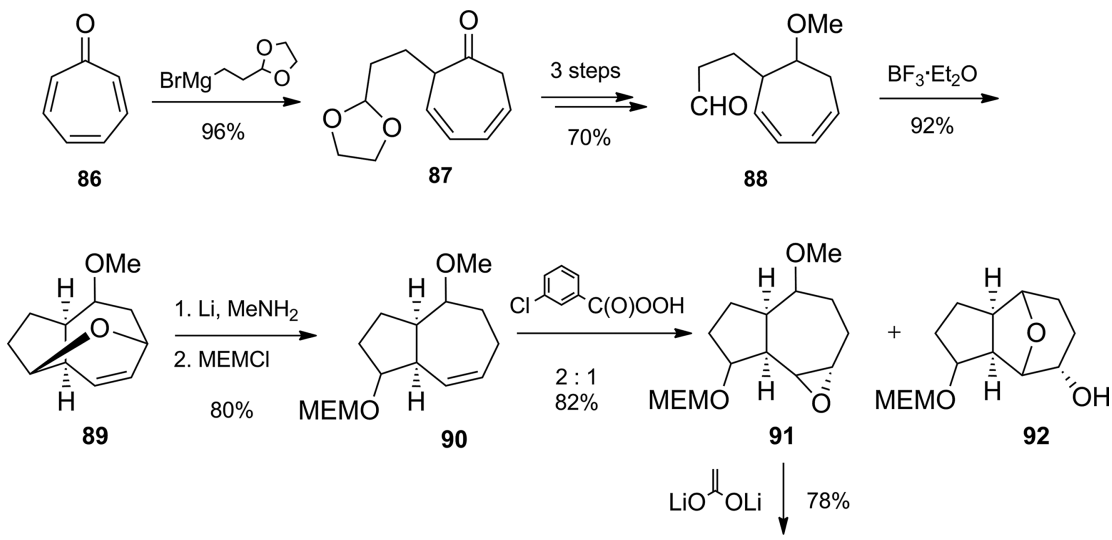

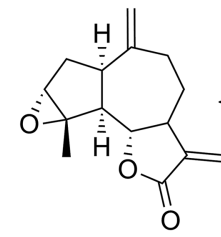

( \pm )-Estafiatin (53)

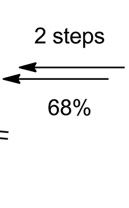

( \pm )-Dehydrocostuslactone (3)

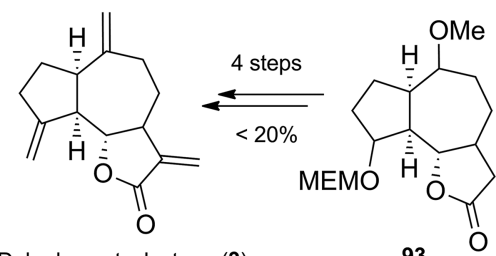

93

Scheme 15. Synthesis of ( \pm )-dehydrocostuslactone and ( \pm )-estafiatin.

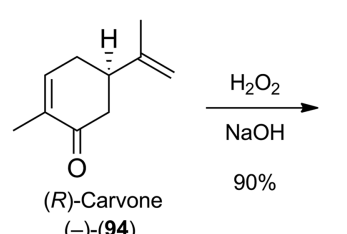

$(-)-(94)$

THPO,<smiles>C=C(C)[C@H]1C[C@@H](O)[C@@H](C)[C@H]1C(=O)OC</smiles>

THPO,

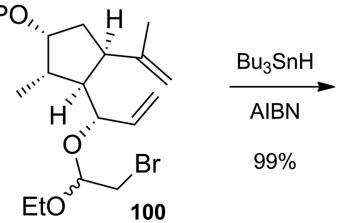

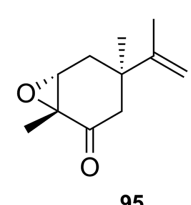

95

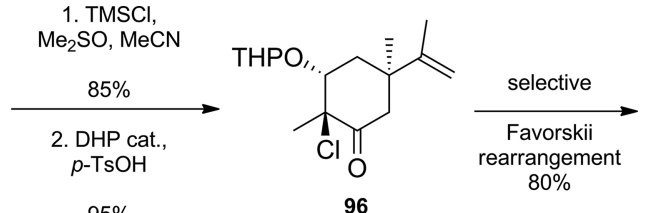

$95 \%$

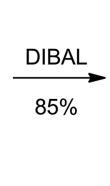

THPO,<smiles>C=C(C)[C@H]1CC(O)[C@@H](C)[C@H]1C=O</smiles><smiles>CCO[C@@H]1C[C@@H]2CC[C@H](C)[C@H]3C[C@H](OP)[C@@H](C)[C@H]3[C@@H]2O1</smiles>

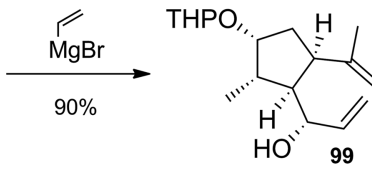
$\mathrm{Br}^{\mathrm{O}} \mathrm{Br}$<smiles>CCO[PbH2+]</smiles><smiles>C=C[AsH2]</smiles>
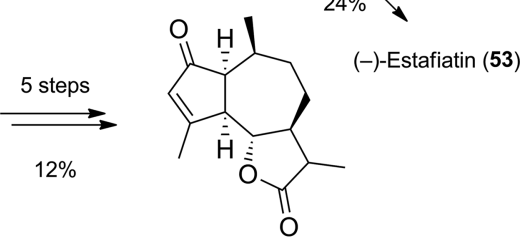

(+)-Cladantholide (102)

Scheme 16. Synthesis of (+)-cladantholide and (-)-estafiatin.

achieved the first absolute stereochemical assignment of thapsivillosin C. ${ }^{[55]}$ These prodrug derivatives showed selective in vivo cytotoxicity against prostate tumors, as well as many other promising activities such as potent histamine liberation and selective and irreversible inhibition of the ubiquitous sarco-endoplasmic reticulum $\mathrm{Ca}^{2+}$ ATP-dependent pumps (SERCAs) up to subnanomolar concentrations. ${ }^{[55 a]}$ The synthetic plan was reported in different publications, in which some potential routes to prepare the guaianolide skeleton were presented along with the iterations that led to the best strategy. The benefits of this approach are the inherent substrate control that governs each newly established stereogenic center. This allowed the generation of thapsigargin (1, Figure 1) as a single diastereoisomer in 42 synthetic steps from $(S)$-carvone $(\mathbf{9 4}$, average yield of $89 \%$ per step).

A concise summary of the strategy used by Ley and coworkers shows a striking similarity between the initial steps and the work reported by Lee et al. (Scheme 17).

Continuing towards the synthesis of thapsigargin, Massanet et al. developed the enantioselective synthesis of 7,11dihydroxyguaianolide $\mathbf{1 2 4}$ with the desired stereochemistry. ${ }^{[56]}$ Their methodology had two key steps: photochemical rearrangement of the eudesmane-like $\gamma, \delta$-unsaturated ketone $\mathbf{1 2 1}$ to give the corresponding guaiane from (+)-dihydrocarvone and the regioselective oxidation of the unpro- 

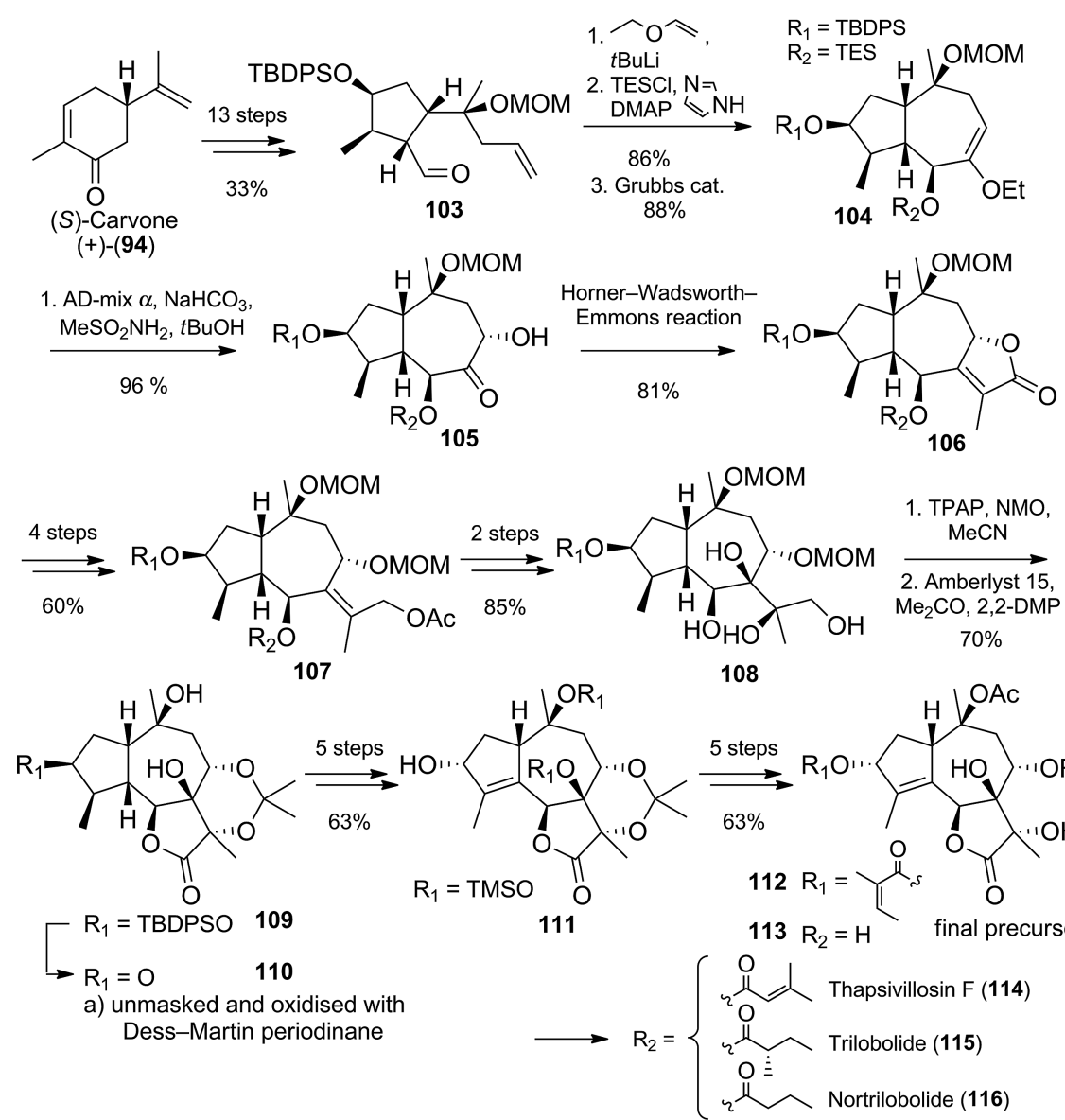

Scheme 17. Synthesis of thapsigargin.

tected tetrahydroxylated ketone $\mathbf{1 2 3}$ to yield the dihydroxy lactone with the required stereochemistry (Scheme 18). Recently, the same group developed $\mathrm{KMnO}_{4}$-promoted $\alpha^{\prime}$ acyloxylation of cyclic enones with linear carboxylic acids.
This methodology has been applied to the synthesis of densely oxygenated guaianolides (Scheme 19). ${ }^{[57]}$

Several other interesting approaches have also been reported. Kozikowski et al. described a method for the syn-

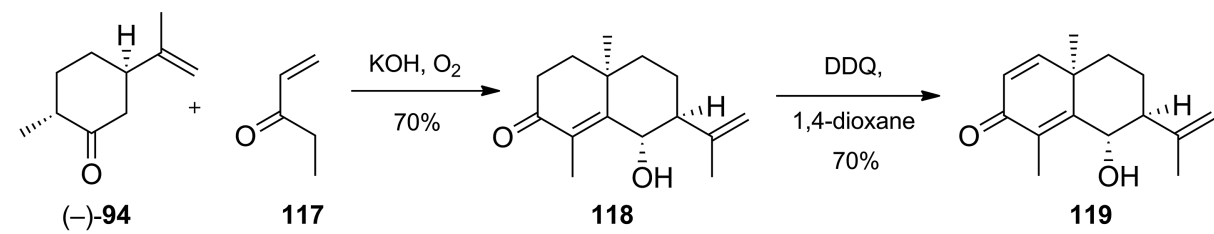
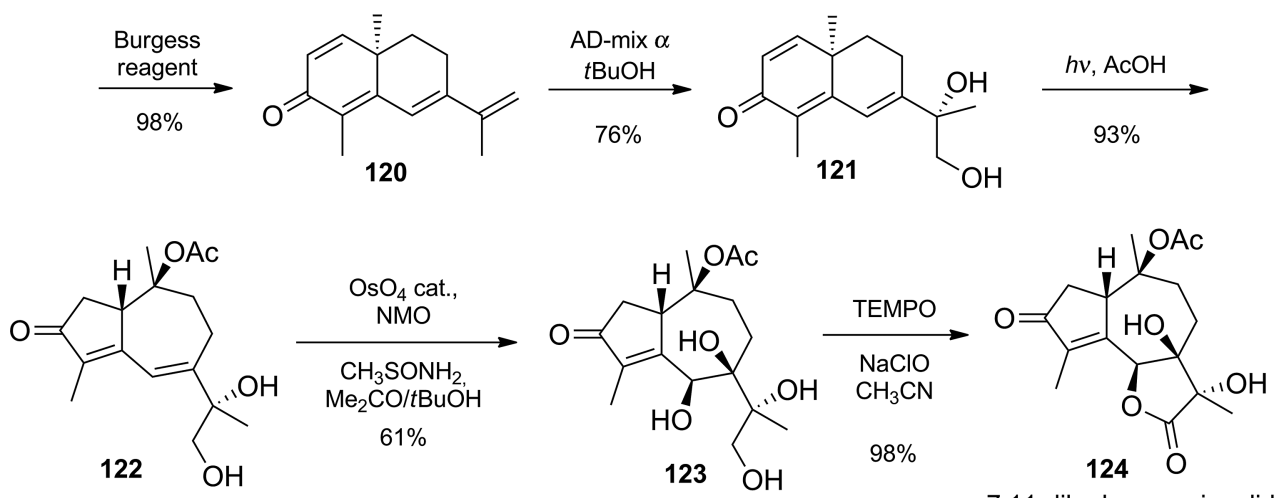

7,11-dihydroxyguaianolide

Scheme 18. Synthesis of 7,11-dihydroxyguaianolides. 


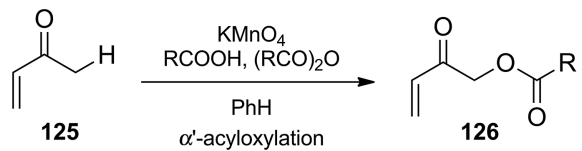<smiles>C=C(C)[C@H]1CC[C@@H](C)C(=O)C1</smiles>

$(-)-(94)$

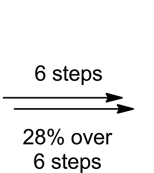

6 steps<smiles>C1CCCCCC1</smiles>

127

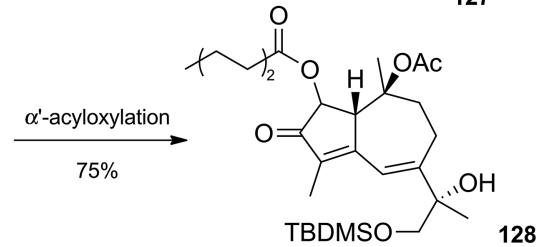

Scheme 19. Scope of the $\alpha^{\prime}$-acyloxylation reaction with guaiane scaffolds.

thesis of the hydroazulenic ring system by an intramolecular nitrile oxide cycloaddition reaction that involved treatment of 3-chlorocyclopent-1-ene with the sodium salt of dimethyl malonate to achieve the coupling. ${ }^{[58]}$ A similar approach was used by Tanis et al. for the synthesis of bicyclo[5.3.0] decane in five steps and in $36 \%$ overall yield by furan-terminated cationic cyclization. ${ }^{[59]}$ In 1990 Monde developed an innovative synthesis of lettucenin A, a guaianolide phytoalexin isolated by the same group from lettuce inoculated with the bacterium Pseudomonas cichorii. ${ }^{[60]}$ This synthesis starts with para-cresol to obtain indanone, and the skeleton of the product was subsequently generated by reductive ring expansion of a dibromomethyl-substituted cyclohexadienone.

In recent years some new strategies that avail themselves of recent advances in organic synthesis have been reported. A promising synthetic route to guaianolides, based on a new multicomponent reaction sequence (MARDi cascade), was presented by Coquerel and Rodriguez et al.. A highly chemoselective domino transformation was subsequently used for the expeditious stereoselective preparation of the tricyclic core. ${ }^{[61]}$ The MARDi cascade with the $\beta$-oxo ester $\mathbf{1 2 9}$ and the crotonaldehyde $\mathbf{1 3 0}$ yielded the cycloheptanol 135 as a single isomer. In the multicomponent reaction (MCR) recently developed by the same group, a Michaelinitiated sequence can be used as an approach to guaianolides because it allows diastereoselective access to a variety of carbo- and heterocyclic seven-membered rings under convenient and environmentally friendly conditions (Scheme 20). ${ }^{62]}$ The key factor in the synthetic application of the MARDi cascade to target-oriented synthesis is the chemo-differentiation of the two carboxylate groups in the products. The reaction allows the control of up to five newly created stereocenters and complete chiral induction in the case of an optically active ketone precursor. The high level of diastereoselectivity observed has been attributed to the overall thermodynamic control of the reaction.

A diastereoselective route to the 5,7,5-tricyclic guaianolide core was presented by Donaldson and co-workers in 2009. ${ }^{[63]}$ This route is based on the Cope rearrangement of divinylcyclopropane 142, which was prepared by alkenyl Grignard exo-addition to a (1-methoxycarbonylpentadienyl $) \mathrm{Fe}(\mathrm{CO})_{3}{ }^{+}$, followed by oxidative decomplexation. An additional key reaction involves oxidative rearrangement of a 3,4-epoxy-1,7-diol to generate a $\gamma$-lactone (Scheme 21).

An interesting variant of the strategy previously reported by Lee et al. and Ley et al. ${ }^{[55 c]}$ for the synthesis of the guaianolide ring system was described by Maier in 2010; it started from $(R)-(-)$-carvone (94) to afford the diazoketone 149 in 13 steps. ${ }^{[64]}$ A bimolecular carbonyl ylide-alkyne cycloaddition reaction was followed by 1,3-cycloaddition of the cyclic carbonyl ylide with a trans-annulated cyclopentane ring to generate an oxygen-bridged polycycle

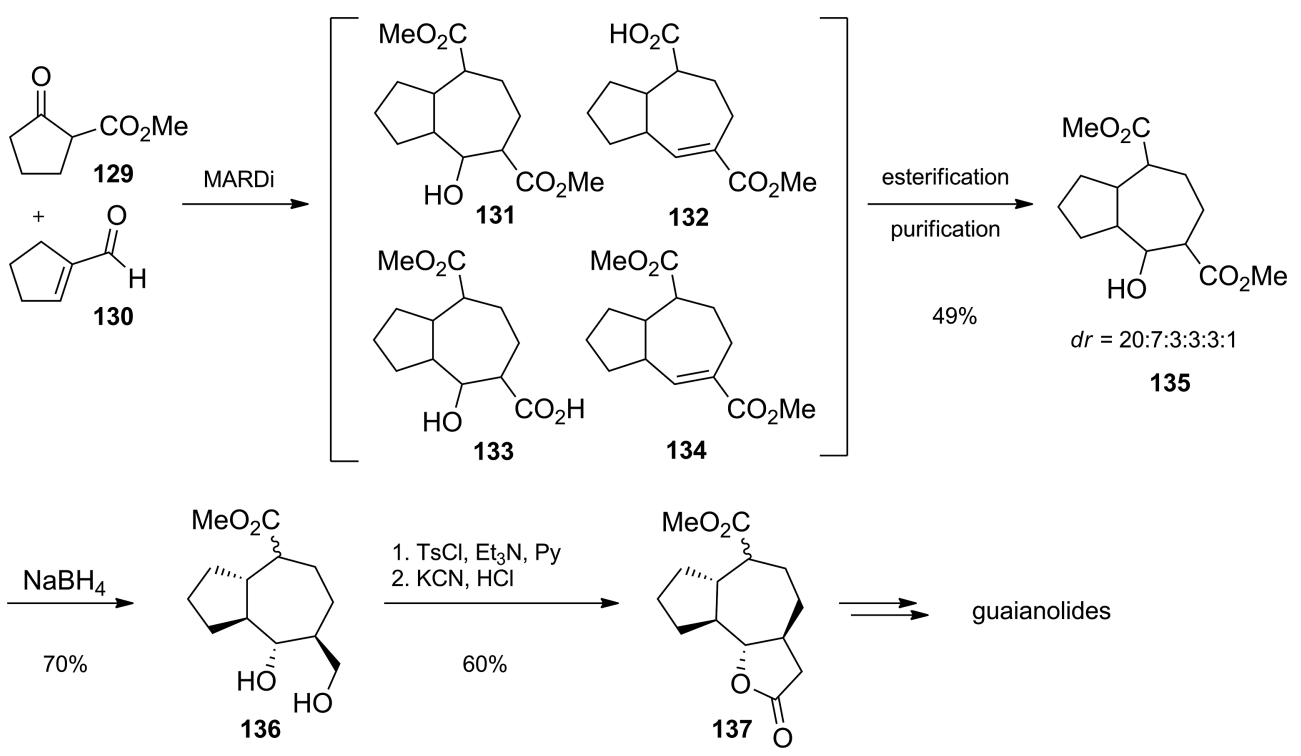

Scheme 20. Approach to guaianolides by the MARDi cascade. 


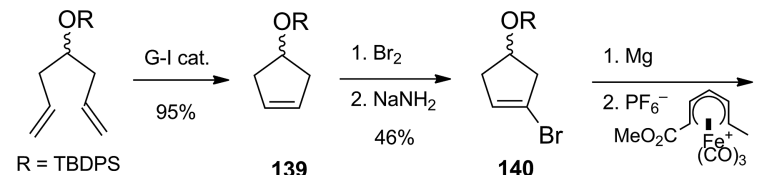
138

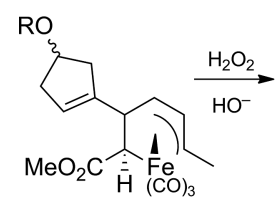

141
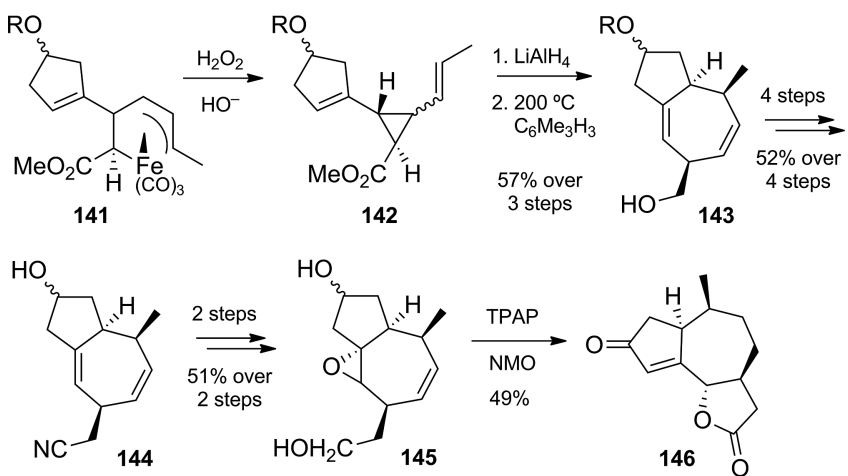

$\mathrm{HO}$
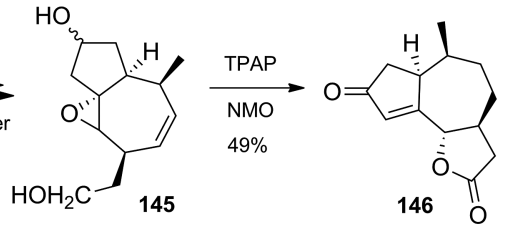

Scheme 21. Approach to guaianolides based on the Cope rearrangement.

stereoselectively through a $\mathrm{Rh}_{2}(\mathrm{OAc})_{4}$-catalyzed reaction from the diazoketone precursor with trapping by allyl propiolate. A Curtius degradation led to transformation of the cycloadduct into the guaianolide skeleton (Scheme 22).
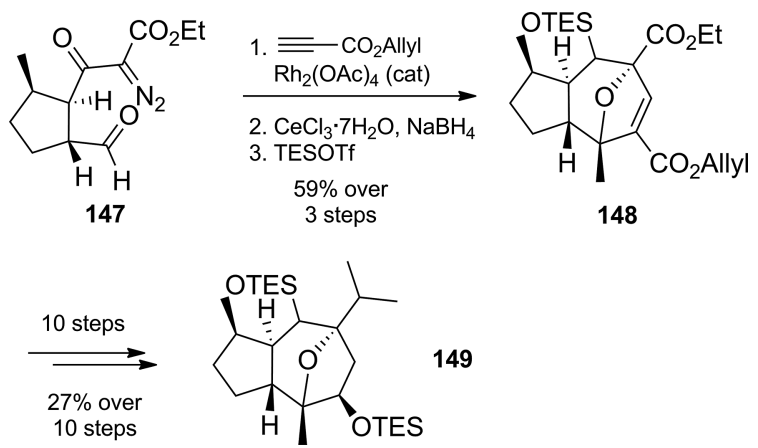

Scheme 22. Synthesis of the guaianolide ring system.

In 2010 Avery et al. designed and developed the synthesis of new guaianolide endoperoxides such as $\mathbf{1 5 5}$ as potential antimalarial agents. ${ }^{[65]}$ These SLs, which are named thaperoxides, were prepared as precursors during the synthesis of thapsigargin, and the compounds have striking structural similarities with artemisinin and thapsigargin (1). An analogous methodology was used to obtain the cyclopentanecarboxylate $\mathbf{1 5 1}$ from $(S)$-carvone (94), ${ }^{[54]}$ and this was transformed into a bis-olefin precursor in four steps. The proposed ring-closing metathesis of the previously obtained precursor cleanly generated the bicyclic intermediate in the presence of the second-generation Grubbs catalyst in high yield. Dess-Martin periodinane oxidation of $\mathrm{C} 6-\mathrm{OH}$ was followed by $\mathrm{C}-7$ homologation by selective kinetic enolization, with ethyl pyruvate as the electrophile, to give the bicyclic ketone 153, which in three steps gave the key inter- mediate for a stereoselective [4+2] cycloaddition of singlet oxygen and introduction of the endoperoxide (Scheme 23).
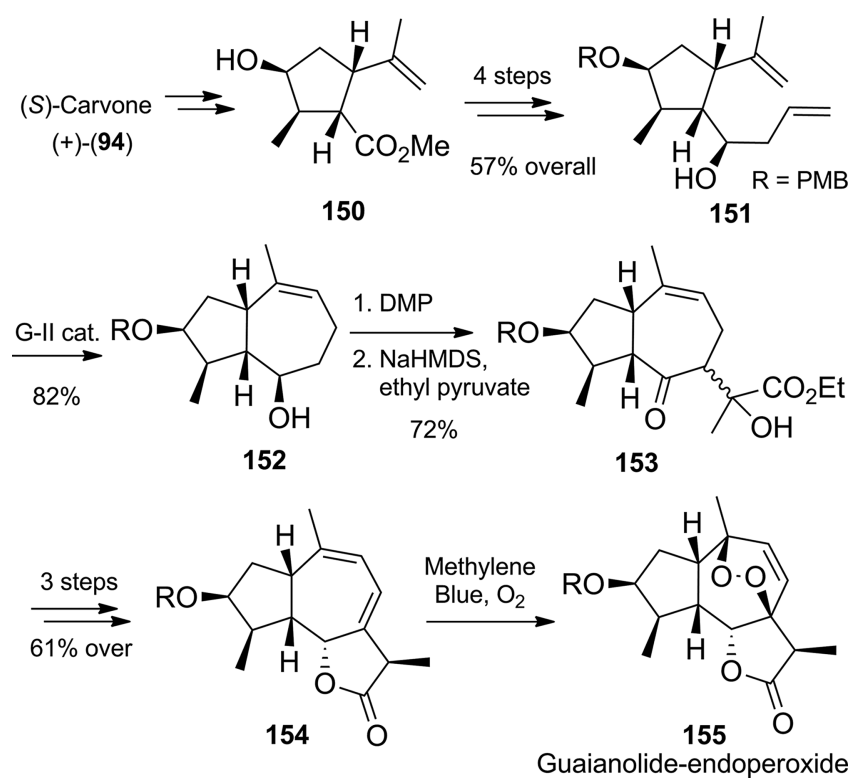

Scheme 23. Synthesis of guaianolide endoperoxide $\mathbf{1 5 5}$.

\section{Hydroazulene-Lactone Strategies Involving Intramolecular Cycloaddition}

Related strategies start with the formation of the lactone ring, with the hydroazulene backbone subsequently obtained by intramolecular cycloaddition.

An innovative strategy for the enantioselective synthesis of (+)-arglabin (2) was presented by Reiser et al. in 2007. ${ }^{[66]}$ This promising natural product, isolated from Artemisia glabella, has been successfully used in Kazakhstan for the treatment of breast, colon, ovarian, and lung cancers. ${ }^{[16 \mathrm{~h}]}$ The synthetic strategy is an extension of the work previously reported by the same group for the enantioselective synthesis of trans-4,5-disubstituted $\gamma$-butyrolactones such as $\mathbf{1 6 0},{ }^{[67]}$ in which allylation of cyclopropane with the allylsilane led to the first key intermediate. A second Sakurai allylation with 2-methylallylsilane and subsequent ring-closing metathesis in the presence of the second-generation Grubbs (G-II) catalyst gave the desired guaiane skeleton 162 (Scheme 24). The synthesis of (+)-arglabin (2) was completed in further steps, which included removal of the hydroxy group by the Barton-McCombie protocol and $\alpha$ methylenation.

In the same year $\mathrm{Xu}$ and co-workers completed the first total synthesis of ent-8-epi-grosheimin $\mathbf{1 6 8}$ in an approach based entirely on substrate-controlled methods. ${ }^{[68]}$ The strategy featured the formation of the C-ring before addressing the construction of the B-ring from cyclopentyl carbaldehyde 164, obtained by a procedure similar to that described by Lee et al. ${ }^{[53]}$ The key steps were a stereoselective Mukaiyama aldol addition, an oxidative $\gamma$-lactonization, and an intramolecular aldehyde-ene cyclization (Scheme 25). 


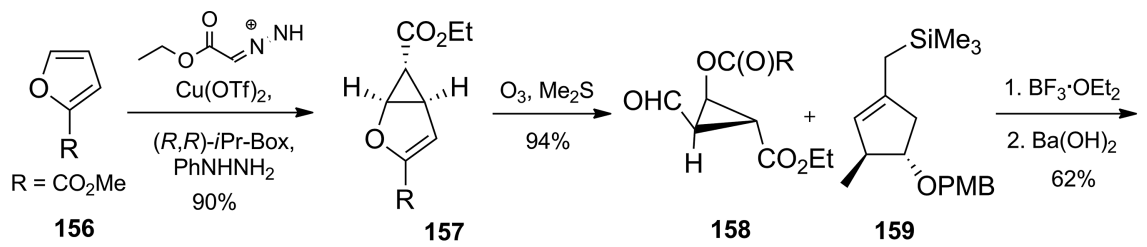

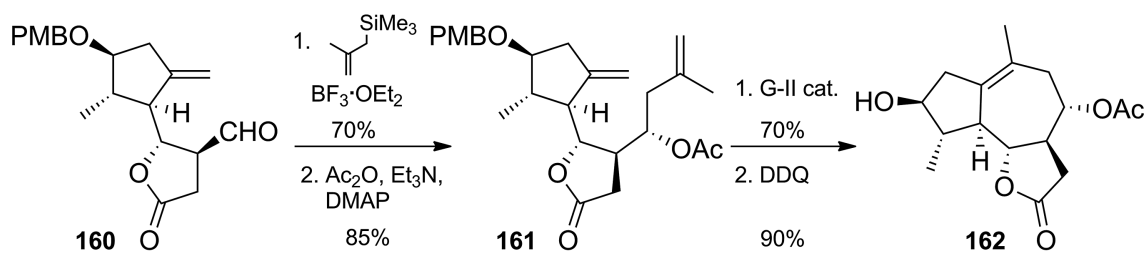

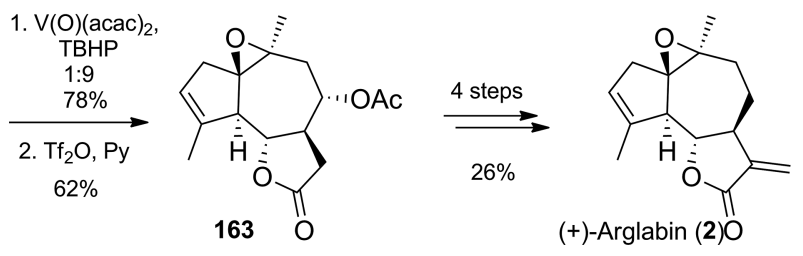

Scheme 24. Synthesis of (+)-arglabin.
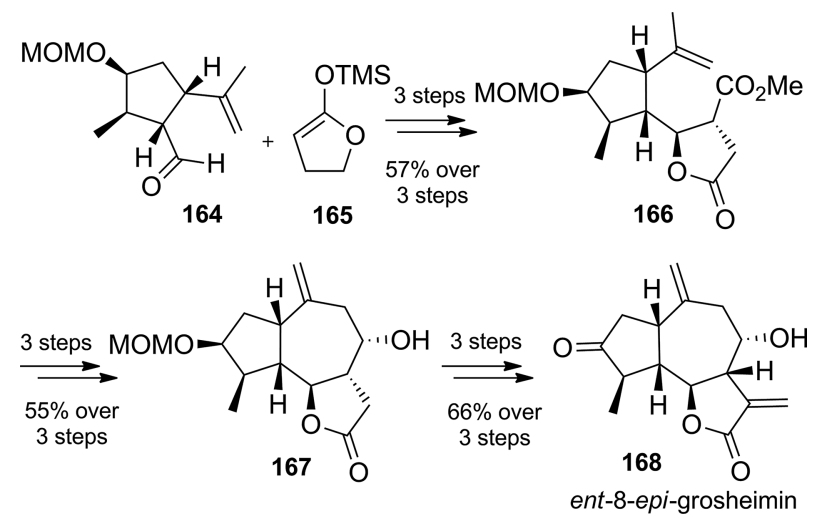

Scheme 25. Synthesis of ent-8-epi-grosheimin.

Recently a powerful synthesis of highly oxygenated 6,12guaianolide analogues was described by Brummond and co-workers. ${ }^{[69]}$ The scope of the tandem allylboration/lactonization chemistry established by Hall[ ${ }^{[70]}$ was expanded to provide functionalized allene-yne-containing $\alpha$-methylene butyrolactone 173, which underwent a $\mathrm{Rh}^{\mathrm{I}}$-catalyzed cyclocarbonylation reaction to afford the 5,7,5-ring system 174. In a previous report, ${ }^{[69 a]}$ the benefits of the early-stage incorporation of an $\alpha$-methylene butyrolactone for the $\mathrm{Rh}^{\mathrm{I}}$ catalyzed allenic Pauson-Khand reaction (APKR) were demonstrated.

The methodology starts with allenyl ester 169, obtained from a monoprotected butynediol through a JohnsonClaisen rearrangement. Ester 169 reacted with methoxymethylamine hydrochloride and isopropylmagnesium chloride to afford the corresponding Weinreb amide, which was converted into alkynone $\mathbf{1 7 0}$ by treatment with ethynylmagnesium bromide. Reduction of the carbonyl group of the ynone with lithium aluminum hydride, direct conversion into the corresponding methyl ether, deprotonation of the terminus of the alkyne with $n \mathrm{BuLi}$, and addition of methyl chloroformate gave the alkynoate 171. Treatment of $\mathbf{1 7 1}$ with DIBAL, $\mathrm{CuI}, \mathrm{MeLi}$, and $\mathrm{ClCH}_{2} \mathrm{BPin}$ gave allylboronates in a $Z / E$ ratio of 1.2:1. These compounds were not separated, and the mixture was subjected to an allylboration/lactonization step by heating with 3-phenylpropiolaldehyde to obtain a complex mixture. Treatment of this complex mixture with PTSA produced lactone trans-173 as a 2:1 mixture of diastereoisomers, and subsequent treatment with rhodium biscarbonyl chloride dimer and removal of the TBDPS group yielded the cyclocarbonylation product as a mixture of diastereoisomers (Scheme 26).

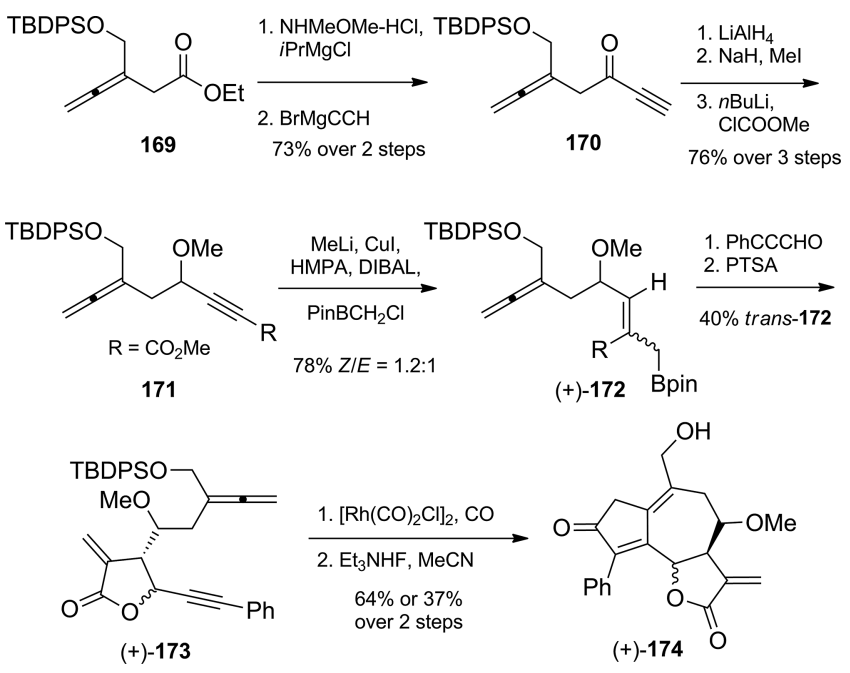

Scheme 26. Synthesis of 6,12-guaianolide analogues.

A very recent strategy was presented by Winne et al., ${ }^{[1]}$ who assembled the guaianolide ring system in three straightforward synthetic operations by using a highly diastereoselective intramolecular [4+3] cycloaddition reaction 
of a catalytically generated furfuryl cation intermediate. The first precursor was generated in two steps by treating the anion derived from furan $\beta$-keto ester $\mathbf{1 7 6}$ with bromodiene 175. Reduction of the resulting alkylated product with sodium borohydride gave the corresponding diastereomeric $\beta$-hydroxy esters. After persistent investigation. and in search of a more "natural" guaianolide ring system, the second precursor was treated with catalytic amounts of gallium(III) triflate, a highly reactive Lewis acid, to give a rather clean conversion to 6,12-furanoguaine cycloadducts 177 and 178 (Scheme 27).

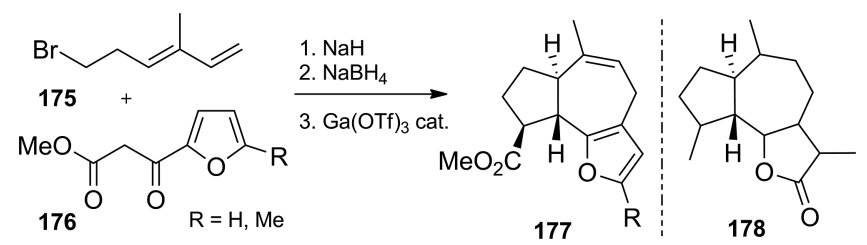

Scheme 27. Three-step synthesis of the guaianolide ring system.

\section{Hydroazulene Strategies Based on Intermolecular Cycloaddition}

Hydroazulenes can also be obtained by stereocontrolled cycloaddition of two precursors followed by some modifications.

As mentioned above, Vandewalle et al. achieved the total synthesis of the guaianolides $( \pm)$-compressanolide (189) and ( \pm )-estafiatin (53) in 1983. ${ }^{[49]} \mathrm{A}$ general and efficient route to the functionalized guaiane skeleton previously having been reported, $( \pm)$-compressanolide was obtained from the perhydroazulenic lactone $\mathbf{1 8 8}$ in five steps. This lactone had previously been obtained in nine steps by starting from cyclopent-2-enone (179) and generating the diketone $( \pm)$ 183. ${ }^{[72]}( \pm)$-Estafiatin was obtained from the lactone intermediate 190 in six steps including an epimerization. A summary of the total synthesis in which non-naturally occurring guaianolides have been described is shown in Scheme 28 and this involves the rearrangement of a functionalized intermediate $\mathbf{1 8 2}$.

The methodology outlined above includes a [2+2] photocycloaddition between 1,2-bis(trimethylsilyloxy)cyclopentene (180) and cyclopent-2-enone (179), followed by nucleophilic addition to the ketone and an $\alpha$-diol oxidative cleavage of the resulting triol to yield the perhydroazulenedione 183, which provided access to the two desired products.

In 1992, Jacobi et al. presented a new synthetic approach involving a Diels-Alder/retro Diels-Alder transformation of an acetylenic oxazole to synthesize $( \pm)$-geigerin (196, Scheme 29). ${ }^{[73]}$ Geigerin was isolated in 1936 from Geigeria aspera Harv., a south African species. ${ }^{[74]}$

In $2003^{[75]}$ Deprés et al. reported a versatile synthetic approach in which they found that 7-methylcycloheptatriene, obtained from the commercially available tropyllium cation (191) in $43 \%$ overall yield, underwent a regio- and stereoselective cycloaddition and a dichloroketene ring expansion/ elimination sequence of the [2+2] cycloadduct with diazomethane to give hydroazulenone 193. The same hydrozulenone was used years later as an intermediate in the total synthesis of $( \pm)$-geigerin (196, Scheme 29). ${ }^{[76]}$ A similar strategy was reported by the same group in the total synthesis of $\Delta$-11,13-didehydroguaianes and -guaianolides

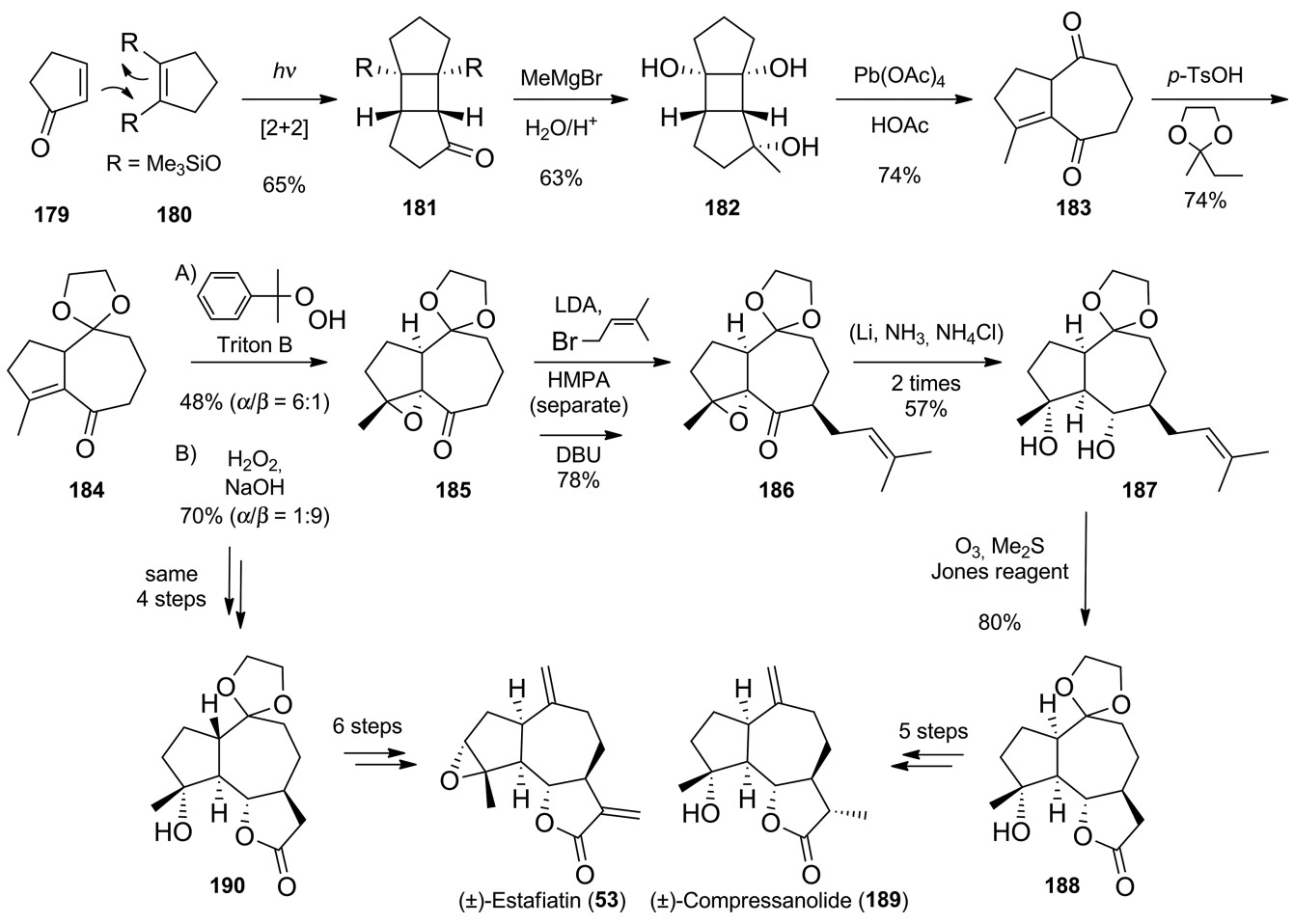

Scheme 28. Synthesis of ( \pm )-compressanolide and ( \pm )-estafiatin. 

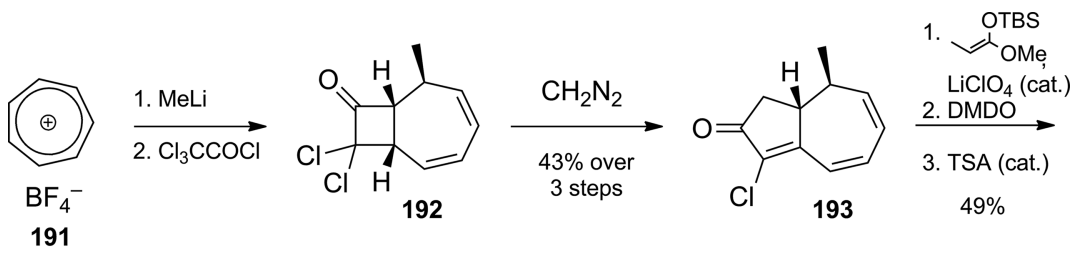

191
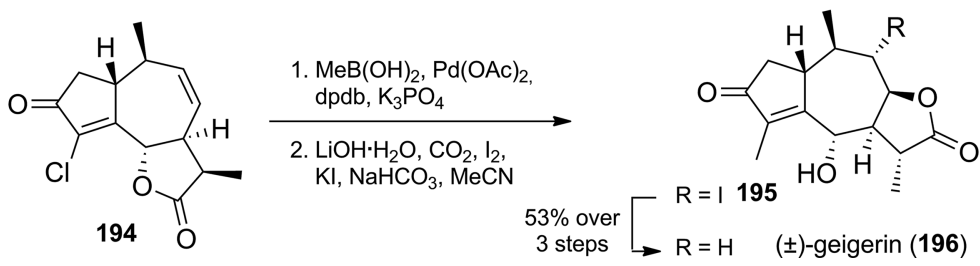

Scheme 29. Synthesis of $( \pm)$-geigerin.

such as $( \pm)$-achalensolide and $( \pm)$-pechueloic acid in 2009. [77]

Several approaches involving [2+2] cycloadditions have also been reported to generate guaianolides and pseudoguaianolides. For example, Schore reported the synthesis of 11-oxatricyclo[5.3.1.0] undecane derivatives through the $\mathrm{Co}_{2}$ - $(\mathrm{CO})_{8}$-catalyzed cyclization of alkenes with various 8-oxabicyclo[3.2.1] oct-6-ene derivatives. ${ }^{[78]}$ Lange et al. achieved the synthesis of four sesquiterpene lactones from the photoadduct previously prepared by [2+2] cycloaddition between cyclobutene-1-carboxylic acid and the diastereomeric enone with use of a $350 \mathrm{~nm}$ irradiation source. ${ }^{[79]}$

\section{Conclusions}

Natural products such as guaianolides and their derivatives have for decades served as an important class of targets, in large measure because of their demonstrated efficacy as bioactive agents. These compounds provide inspiration for the development of new chemistry, as well as allowing the use of newly developed synthetic capabilities to define the necessary methodologies.

As highlighted above, the synthesis of guaianolides has always been a challenge, due to the structural diversity of these compounds. Numerous methodologies have been described, and these have encompassed a tremendous variety of synthetic strategies. The approaches can be classified into two main groups: semi-synthesis and total synthesis.

In semi-synthesis most of the stereogenic centers are already preformed; santonin has proven to be a practical starting material thanks to the improvement in the highyielding photochemical reaction to obtain the guaianolide skeleton. This key step has been reported for the synthesis of promising products such as seco-guaianolides and dimeric guaianolides. ${ }^{[41,43 b, 46]}$

The total synthesis approach involves the generation of stereocenters by diastereoselective cycloadditions. Other useful synthetic methodologies such as MARDi cascade, transition-metal catalysis, or ring-closing metathesis have also been introduced. ${ }^{[66,61,80]}$ In recently reported strategies the aim has been to obtain guaianolides in high yields in the fewest possible steps. ${ }^{[71]}$

\section{Acknowledgments}

This research was supported by the Ministerio de Economía y Competitividad (MINECO) (project number AGL2013-42238-R), the Consejería de Economía Innovación y Ciencia, and the Junta de Andalucía (project number AGR-5822-2011).

[1] F. A. Macias, A. Santana, A. G. Duran, A. Cala, J. C. G. Galindo, J. L. G. Galindo, J. M. G. Molinillo, ACS Symp., Ser. 2013, 1141, 167-188.

[2] K. Zan, X.-Q. Chen, P.-F. Tu, Chin. J. Nat. Medicines 2012, 10, 358-362.

[3] R. R. A. Kitson, A. Millemaggi, R. J. K. Taylor, Angew. Chem. Int. Ed. 2009, 48, 9426-9451; Angew. Chem. 2009, 121, 9590.

[4] M. R. Kreuger, S. Grootjans, M. W. Biavatti, P. Vandenabeele, K. D'Herde, Anti-Cancer Drugs 2012, 23, 883-896.

[5] M. Saikali, A. Ghantous, R. Halawi, S. Talhouk, N. Saliba, N. Darwiche, BMC Complementary Altern. Med. 2012, 12, 89.

[6] B. M. Fraga, Nat. Prod. Rep. 2013, 30, 1226-1264.

[7] A. Schall, O. Reiser, Eur. J. Org. Chem. 2008, 2353-2364.

[8] H. Simonsen, C. Weitzel, S. Christensen, in: Natural Products (Eds.: K. G. Ramawat, J.-M. Mérillon), Springer, Berlin/Heidelberg, 2013, p. 3069-3098.

[9] J. H. Rigby, J. Z. Wilson, J. Am. Chem. Soc. 1984, 106, 82178224.

[10] P. S. Kalsi, G. Kaur, S. Sharma, K. K. Talwar, Phytochemistry 1984, 23, 2855-2861.

[11] A. G. González, A. D. de la Rosa, G. M. Massanet, Phytochemistry 1982, 21, 895-897.

[12] I. G. Collado, F. A. Macias, G. M. Massanet, J. M. G. Molinillo, F. Rodriguez-Luis, J. Org. Chem. 1987, 52, 3323-3326.

[13] F. A. Macias, J. C. G. Galindo, G. M. Massanet, Phytochemistry 1992, 31, 1969-1977.

[14] a) F. A. Macías, D. Castellano, J. M. G. Molinillo, J. Agric. Food Chem. 2000, 48, 2512-2521; b) F. A. Macias, J. C. G. Galindo, D. Castellano, R. Velasco, J. Agric. Food Chem. 2000, 48, 5288-5296.

[15] Y.-H. Ding, H.-X. Fan, J. Long, Q. Zhang, Y. Chen, Bioorg. Med. Chem. Lett. 2013, 23, 6087-6092.

[16] a) O. V. Alebastrov, S. A. Pigiltsova, G. A. Atazhanova, V. A. Raldugin, M. M. Shakirov, I. Y. Bagryanskaya, Y. V. Gatilov, A. T. Kulyjiasov, S. M. Adekenov, G. A. Tolstikov, Russ. Chem. Bull. 2000, 49, 1902-1904; b) O. V. Alebastrov, V. A. Raldugin, I. Y. Bagryanskaya, Y. V. Gatilov, M. M. Shakirov, A. T. Kulyjasov, S. M. Adekenov, Russ. Chem. Bull. 2003, 52, 1449- 
1451; c) O. V. Alebastrov, V. A. Raldugin, I. Y. Bagryanskaya, Y. V. Gatilov, M. M. Shakirov, A. T. Kulyyasov, S. M. Adekenov, Chem. Nat. Compd. 2003, 39, 362-365; d) S. A. Ivasenko, A. T. Kulyyasov, S. M. Adekenov, Chem. Nat. Compd. 2003, 39, 601-602; e) R. I. Jalmahanbetova, B. B. Rakhimova, V. A. Raldugin, I. Y. Bagryanskaya, Y. V. Gatilov, M. M. Shakirov, A. T. Kulyjasov, S. M. Adekenov, G. A. Tolstikov, Russ. Chem. Bull. 2003, 52, 748-751; f) R. I. Dzhalmakhanbetova, S. A. Ivasenko, A. T. Kulyyasov, B. B. Khasenov, N. B. Kurmankulov, S. M. Adekenov, Chem. Nat. Compd. 2004, 40, 381-386; g) S. A. Ivasenko, R. I. Dzhalmakhanbetova, A. T. Kulyyasov, N. B. Kurmankulov, S. M. Adekenov, Chem. Nat. Compd. 2004, 40, 387-390; h) N. S. Zhangabylov, L. Y. Dederer, L. B. Gorbacheva, S. V. Vasil'eva, A. S. Terekhov, S. M. Adekenov, Pharm. Chem. J. 2004, 38, 651-653; i) R. I. Dzhalmakhanbetova, V. A. Raldugin, I. Y. Bagryanskaya, Y. V. Gatilov, M. M. Shakirov, G. A. Atazhanova, S. M. Adekenov, Khim. Interesakh Ustoich. Razvit. 2007, 15, 545-548; j) R. I. Jalmakhanbetova, G. A. Atazhanova, V. A. Raldugin, I. Y. Bagryanskaya, Y. V. Gatilov, M. M. Shakirov, S. M. Adekenov, Chem. Nat. Compd. 2007, 43, 548-551; k) R. I. Jalmakhanbetova, V. A. Raldugin, I. Y. Bagryanskaya, Y. V. Gatilov, M. M. Shakirov, G. A. Atazhanova, S. M. Adekenov, Chem. Nat. Compd. 2007, 43, 552-554; 1) R. I. Dzhalmakhanbetova, Y. V. Gatilov, M. M. Shakirov, G. A. Atazhanova, S. M. Adekenov, Chem. Nat. Compd. 2010, 46, 222-226; m) S. M. Adekenov, Chem. Nat. Compd. 2013, 48, 988-995.

[17] P. Barbetti, G. Fardella, I. Chiappini, V. Scarcia, A. Furlani Candiani, Eur. J. Med. Chem. 1989, 24, 299-305.

[18] R. Csuk, A. Heinold, B. Siewert, S. Schwarz, A. Barthel, R. Kluge, D. Stroehl, Arch. Pharm. (Weinheim, Ger.) 2012, 345, 215-222.

[19] S. H. Lone, K. A. Bhat, Shakeel-u-Rehman, R. Majeed, A. Hamid, M. A. Khuroo, Bioorg. Med. Chem. Lett. 2013, 23, 4931-4934.

[20] F. Shafizadeh, N. R. Bhadane, J. Org. Chem. 1972, 37, 31683173.

[21] O. S. Giordano, M. J. Pestchanker, E. Guerreiro, J. R. Saad, R. D. Enriz, A. M. Rodriguez, E. A. Jauregui, J. Guzman, A. O. M. Maria, G. H. Wendel, J. Med. Chem. 1992, 35, 24522458.

[22] M. Bruno, S. Rosselli, A. Maggio, R. A. Raccuglia, K. F. Bastow, K.-H. Lee, J. Nat. Prod. 2005, 68, 1042-1046.

[23] A. Gonzalez Gonzalez, A. Galindo, H. Mansilla, Tetrahedron 1980, 36, 2015-2017.

[24] A. G. Gonzalez, A. Galindo, M. Mar Afonso, H. Mansilla, M. Lopez, Tetrahedron 1988, 44, 4585-4589.

[25] A. Gonzalez, A. Galindo, J. A. Palenzuela, H. Mansilla, Tetrahedron Lett. 1986, 27, 2771-2774.

[26] M. Bordoloi, J. C. Sarmah, R. P. Sharma, Tetrahedron 1989, 45, 289-302.

[27] J. Castañeda-Acosta, N. H. Fischer, D. Vargas, J. Nat. Prod. 1993, 56, 90-98.

[28] Q. Zhang, Y. Lu, Y. Ding, J. Zhai, Q. Ji, W. Ma, M. Yang, H. Fan, J. Long, Z. Tong, Y. Shi, Y. Jia, B. Han, W. Zhang, C. Qiu, X. Ma, Q. Li, Q. Shi, H. Zhang, D. Li, J. Zhang, J. Lin, L.-Y. Li, Y. Gao, Y. Chen, J. Med. Chem. 2012, 55, 8757-8769.

[29] R. Azarken, F. M. Guerra, F. J. Moreno-Dorado, Z. D. Jorge, G. M. Massanet, Tetrahedron 2008, 64, 10896-10905.

[30] G. Blay, L. Cardona, B. García, J. R. Pedro, in: Stud. Nat. Prod. Chem. vol. 24, part E (Ed.: Atta-ur-Rahman), Elsevier, 2000, p. 53-129.

[31] D. H. R. Barton, P. de Mayo, M. Shafiq, J. Chem. Soc. (Res.) 1958, 3314-3319.

[32] A. Natarajan, C. K. Tsai, S. I. Khan, P. McCarren, K. N. Houk, M. A. Garcia-Garibay, J. Am. Chem. Soc. 2007, 129, 9846-9847.

[33] a) J. N. Marx, E. H. White, Tetrahedron 1969, 25, 2117-2120; b) E. H. White, S. Eguchi, J. N. Marx, Tetrahedron 1969, 25, 2099-2115.
[34] R. E. K. Winter, R. F. Lindauer, Tetrahedron 1976, 32, 955959.

[35] M. J. Bordoloi, R. P. Sharma, J. C. Sarma, Tetrahedron Lett. 1986, 27, 4633-4634.

[36] a) M. T. Edgar, A. E. Greene, P. Crabbe, J. Org. Chem. 1979, 44, 159-160; b) A. E. Greene, M. T. Edgar, J. Org. Chem. 1989, $54,1468-1470$.

[37] a) M. Ando, A. Akahane, H. Yamaoka, K. Takase, J. Org. Chem. 1982, 47, 3909-3916; b) M. Ando, H. Yamaoka, K. Takase, Chem. Lett. 1982, 501-504; c) M. Ando, A. Ono, K. Takase, Chem. Lett. 1984, 493-496; d) M. Ando, H. Kusaka, H. Ohara, K. Takase, H. Yamaoka, Y. Yanagi, J. Org. Chem. 1989, 54, 1952-1960; e) M. Ando, Yuki Gosei Kagaku Kyokaishi 1992, 50, 858-874; f) M. Ando, K. Ibayashi, N. Minami, T. Nakamura, K. Isogai, H. Yoshimura, J. Nat. Prod. 1994, 57, 433-445; g) F. Shimoma, H. Kusaka, K. Wada, H. Azami, M. Yasunami, T. Suzuki, H. Hagiwara, M. Ando, J. Org. Chem. 1998, 63, 920-929; h) S. Yuuya, H. Hagiwara, T. Suzuki, M. Ando, A. Yamada, K. Suda, T. Kataoka, K. Nagai, J. Nat. Prod. 1999, 62, 22-30.

[38] M. Ando, A. Akahane, K. Takase, Chem. Lett. 1978, 7, 727730.

[39] a) G. Blay, V. Bargues, L. Cardona, A. M. Collado, B. Garcia, M. C. Munoz, J. R. Pedro, J. Org. Chem. 2000, 65, 2138-2144; b) G. Blay, L. Cardona, B. Garcia, L. Lahoz, B. Monje, J. R. Pedro, Tetrahedron 2000, 56, 6331-6338; c) V. Bargues, G. Blay, L. Cardona, B. Garcia, J. R. Pedro, J. Nat. Prod. 2002, 65, 1703-1706.

[40] F. F. P. Arantes, L. C. A. Barbosa, C. R. A. Maltha, A. J. Demuner, P. Marçal da Costa, J. R. O. Ferreira, L. V. Costa-Lotufo, M. O. Moraes, C. Pessoa, Eur. J. Med. Chem. 2010, 45, 6045-6051.

[41] W. Zhang, S. Luo, F. Fang, Q. Chen, H. Hu, X. Jia, H. Zhai, J. Am. Chem. Soc. 2004, 127, 18-19.

[42] V. Herout, F. Sorm, Collect. Czech. Chem. Commun. 1953, 18, 854-869.

[43] a) C. Li, X. Yu, X. Lei, Org. Lett. 2010, 12, 4284-4287; b) C. Li, L. Dian, W. Zhang, X. Lei, J. Am. Chem. Soc. 2012, 134, 12414-12417.

[44] D. Xia, Y. Du, Z. Yi, H. Song, Y. Qin, Chem. Eur. J. 2013, 19, 4423-4427.

[45] E. F. Makiyi, R. F. Frade, T. Lebl, E. G. Jaffray, S. E. Cobb, A. L. Harvey, A. M. Slawin, R. T. Hay, N. J. Westwood, Eur. J. Org. Chem. 2009, 5711-5715.

[46] F. A. Macias, A. Santana, A. Yamahata, R. M. Varela, F. R. Fronczek, J. M. G. Molinillo, J. Nat. Prod. 2012, 75, 19671973.

[47] a) R. A. Kretchmer, W. J. Thompson, J. Am. Chem. Soc. 1976, 98, 3379-3380; b) J. A. Marshall, R. H. Ellison, J. Am. Chem. Soc. 1976, 98, 4312-4313; c) P. A. Grieco, Y. Ohfune, G. Majetich, J. Am. Chem. Soc. 1977, 99, 7393-7395; d) G. H. Posner, G. L. Loomis, R. D. Mittal, W. J. Frazee, D. M. Schmit, K. A. Babiak, Tetrahedron Lett. 1978, 19, 4213-4216; e) P. T. Lansbury, D. G. Hangauer, J. P. Vacca, J. Am. Chem. Soc. 1980, 102, $3964-3965$; f) P. T. Lansbury, D. G. Hangauer Jr., Tetrahedron Suppl. 1981, 371-378; g) P. Metz, H. J. Schaefer, Tetrahedron Lett. 1982, 23, 4067-4070.

[48] B. Föhlisch, R. Flogaus, G. H. Henle, S. Sendelbach, S. Henkel, Eur. J. Org. Chem. 2006, 2160-2173.

[49] a) A. A. Devreese, P. J. De Clercq, M. Vandewalle, Tetrahedron Lett. 1980, 21, 4767-4770; b) M. Demuynck, A. A. Devreese, P. J. De Clercq, M. Vandewalle, Tetrahedron Lett. 1982, 23, 2501-2504; c) A. A. Devreese, M. Demuynck, P. J. De Clercq, M. Vandewalle, Tetrahedron 1983, 39, 3049-3054; d) A. A. Devreese, M. Demuynck, P. J. De Clercq, M. Vandewalle, Tetrahedron 1983, 39, 3039-3048.

[50] G. H. Posner, K. A. Babiak, G. L. Loomis, W. J. Frazee, R. D. Mittal, I. L. Karle, J. Am. Chem. Soc. 1980, 102, 7498-7505.

[51] J. H. Rigby, Tetrahedron Lett. 1982, 23, 1863-1866. 
[52] J. H. Rigby, C. Senanayake, J. Am. Chem. Soc. 1987, 109, 31473149.

[53] E. Lee, J. W. Lim, C. H. Yoon, Y.-s. Sung, Y. K. Kim, M. Yun, S. Kim, J. Am. Chem. Soc. 1997, 119, 8391-8392.

[54] E. Lee, C. H. Yoon, J. Chem. Soc., Chem. Commun. 1994, 479481.

[55] a) S. F. Oliver, K. Hoegenauer, O. Simic, A. Antonello, M. D. Smith, S. V. Ley, Angew. Chem. Int. Ed. 2003, 42, 5996-6000; Angew. Chem. 2003, 115, 6178; b) S. V. Ley, A. Antonello, E. P. Balskus, D. T. Booth, S. B. Christensen, E. Cleator, H. Gold, K. Hoegenauer, U. Huenger, R. M. Myers, S. F. Oliver, O. Simic, M. D. Smith, H. Sohoel, A. J. A. Woolford, Proc. Natl. Acad. Sci. USA 2004, 101, 12073-12078; c) S. P. Andrews, M. Ball, F. Wierschem, E. Cleator, S. Oliver, K. Hoegenauer, O. Simic, A. Antonello, U. Huenger, M. D. Smith, S. V. Ley, Chem. Eur. J. 2007, 13, 5688-5712; d) S. P. Andrews, M. M. Tait, M. Ball, S. V. Ley, Org. Biomol. Chem. 2007, 5, 14271436.

[56] F. L. Manzano, F. M. Guerra, F. J. Moreno-Dorado, Z. D. Jorge, G. M. Massanet, Org. Lett. 2006, 8, 2879-2882.

[57] R. Marin-Barrios, A. L. Garcia-Cabeza, F. J. Moreno-Dorado, F. M. Guerra, G. M. Massanet, J. Org. Chem. 2014, 79, 65016509.

[58] A. P. Kozikowski, B. B. Mugrage, B. C. Wang, Z. Xu, Tetrahedron Lett. 1983, 24, 3705-3708.

[59] S. P. Tanis, G. M. Johnson, M. C. McMills, Tetrahedron Lett. 1988, 29, 4521-4524.

[60] K. Monde, M. Takasugi, N. Katsui, T. Masamune, Chem. Lett. 1990, 1283-1286.

[61] I. Reboul, T. Boddaert, Y. Coquerel, J. Rodriguez, Eur. J. Org. Chem. 2008, 5379-5382.

[62] Y. Coquerel, M.-H. Filippini, D. Bensa, J. Rodriguez, Chem. Eur. J. 2008, 14, 3078-3092.

[63] J. R. Gone, N. J. Wallock, S. Lindeman, W. A. Donaldson, Tetrahedron Lett. 2009, 50, 1023-1025.

[64] V. Navickas, D. B. Ushakov, M. E. Maier, M. Streobele, H. J. Meyer, Org. Lett. 2010, 12, 3418-3421.
[65] L. Sun, F. Shah, M. A. Helal, Y. Wu, Y. Pedduri, A. G. Chittiboyina, J. Gut, P. J. Rosenthal, M. A. Avery, J. Med. Chem. 2010, 53, 7864-7868.

[66] S. Kalidindi, W. B. Jeong, A. Schall, R. Bandichhor, B. Nosse, O. Reiser, Angew. Chem. Int. Ed. 2007, 46, 6361-6363; Angew. Chem. 2007, 119, 6478.

[67] a) B. Nosse, R. B. Chhor, W. B. Jeong, C. Boehm, O. Reiser, Org. Lett. 2003, 5, 941-944; b) B. Nosse, A. Schall, W. B. Jeong, O. Reiser, Adv. Synth. Catal. 2005, 347, 1869-1874.

[68] H. Yang, X. Qiao, F. Li, H. Ma, L. Xie, X. Xu, Tetrahedron Lett. 2009, 50, 1110-1112.

[69] a) F. Grillet, C. Huang, K. M. Brummond, Org. Lett. 2011, 13, 6304-6307; b) B. Wen, J. K. Hexum, J. C. Widen, D. A. Harki, K. M. Brummond, Org. Lett. 2013, 15, 2644-2647.

[70] J. W. J. Kennedy, D. G. Hall, J. Org. Chem. 2004, 69, 44124428.

[71] J. Hullaert, D. R. Laplace, J. M. Winne, Eur. J. Org. Chem. 2014, 3097-3100.

[72] D. Termont, P. De Clercq, D. De Keukeleire, M. Vandewalle, Synthesis 1977, 46-48.

[73] P. A. Jacobi, K. M. Touchette, H. G. Selnick, J. Org. Chem. 1992, 57, 6305-6313.

[74] C. Rimington, G. C. S. Roets, Onderstepoort J. Vet. Res. 1936, 7, 485-506.

[75] Y. Coquerel, A. E. Greene, J.-P. Depres, Org. Lett. 2003, 5, $4453-4455$.

[76] S. Carret, J.-P. Depres, Angew. Chem. Int. Ed. 2007, 46, 68706873; Angew. Chem. 2007, 119, 6994.

[77] T. Sainte-Luce Banchelin, S. Carret, A. Giannini, J.-P. Depres, Eur. J. Org. Chem. 2009, 3678-3682, S3678/3671-S3678/3622.

[78] a) B. E. La Belle, M. J. Knudsen, M. M. Olmstead, H. Hope, M. D. Yanuck, N. E. Schore, J. Org. Chem. 1985, 50, 52155222; b) V. Sampath, E. C. Lund, M. J. Knudsen, M. M. Olmstead, N. E. Schore, J. Org. Chem. 1987, 52, 3595-3603.

[79] G. L. Lange, M. Lee, J. Org. Chem. 1987, 52, 325-331.

[80] B. Wen, K. M. Brummond, in: ACS Nat. Meet. \& Exp., American Chemical Society, Philadelphia, PA, USA, 2012, p. 417.

Received: September 22, 2014 Published Online: January 15, 2015 